\title{
Contrasting patterns of climatic changes during the Holocene across the Italian Peninsula reconstructed from pollen data
}

\author{
O. Peyron ${ }^{1,2}$, M. Magny ${ }^{1}$, S. Goring ${ }^{3}$, S. Joannin ${ }^{4}$, J.-L. de Beaulieu ${ }^{5}$, E. Brugiapaglia ${ }^{6}$, L. Sadori ${ }^{7}$, G. Garfi ${ }^{8}$, \\ K. Kouli ${ }^{9}$, C. Ioakim $^{10}$, and N. Combourieu-Nebout ${ }^{11}$ \\ ${ }^{1}$ Chrono-Environnement, UMR6249, Université de Franche-Comté, Besançon, France \\ ${ }^{2}$ CBAE, UMR5059, CNRS, Univ. Montpellier 2, Montpellier, France \\ ${ }^{3}$ Department of Geography, Univ. of Wisconsin-Madison, Wisconsin, USA \\ ${ }^{4}$ LGLTPE, UMR5276, Université Lyon 1, France \\ ${ }^{5}$ IMBE, UMR7263, Université Paul Cézanne, Aix-en-Provence, France \\ ${ }^{6}$ D. di Agricoltura, Ambiente e Alimenti, Univ. degli Studi del Molise, Campobasso, Italy \\ ${ }^{7}$ Dipartimento di Biologia Ambientale, Università di Roma "La Sapienza", Roma, Italy \\ ${ }^{8} \mathrm{CNR}$, Istituto di Genetica Vegetale, Corso Calatafimi, Palermo, Italy \\ ${ }^{9}$ Dept. of Hist. Geology, University of Athens, Athens 10679, Greece \\ ${ }^{10}$ Institute of Geology and Mineral Exploration, Olympic Village, Greece \\ ${ }^{11}$ LSCE, UMR8212, Gif-sur-Yvette, France \\ Correspondence to: O. Peyron (odile.peyron@univ-fcomte.fr)
}

Received: 15 November 2012 - Published in Clim. Past Discuss.: 29 November 2012

Revised: 8 March 2013 - Accepted: 17 April 2013 - Published: 14 June 2013

\begin{abstract}
Lake-level records from Italy suggest that patterns of precipitation in the central Mediterranean during the Holocene were divided between the north and south, but a scarcity of reliable palaeoclimatic records in the north and central-southern Mediterranean means new evidence is needed to validate this hypothesis. We provide robust quantitative estimates of Holocene climate in the Mediterranean region using four high-resolution pollen records from northern (Lakes Ledro and Accesa) and southern (Lakes Trifoglietti and Pergusa) Italy. Multiple methods are used to provide an improved assessment of the palaeoclimatic reconstruction uncertainty. The multi-method approach uses the pollenbased weighted averaging, weighted-average partial leastsquares regression, modern analogue technique, and the nonmetric multidimensional scaling/generalized additive model methods. We use independent lake-level data to validate the precipitation reconstructions.

Our results support a climatic partition between northern and southern Italy during the Holocene, confirming the hypothesis of opposing mid-Holocene summer precipitation regimes in the Mediterranean. The northern sites (Ledro, Accesa) are characterized by minima for summer
\end{abstract}

precipitation and lake levels during the early to midHolocene, while the southern sites (Trifoglietti, Pergusa) are marked by maxima for precipitation and lake levels at the same time. Both pollen-inferred precipitation and lake levels indicate the opposite pattern during the late Holocene, a maximum in northern Italy and a minimum in southern Italy/Sicily. Summer temperatures show the same partitioning, with warm conditions in northern Italy and cool conditions in Sicily during the early/mid-Holocene, and a reversal during the late Holocene.

Comparison with marine cores from the Aegean Sea suggests that climate trends and gradients observed in Italy show strong similarities with those recognized from the Aegean Sea, and more generally speaking in the eastern Mediterranean.

\section{Introduction}

The Mediterranean region occupies a transitional zone between mid-latitude and subtropical climates. The Mediterranean climate is commonly defined by wet/mild winters 
and dry/warm to hot summers, but large areas within the Mediterranean do not share this Mediterranean type of climate. The presence of strong mesoscale features that determine large climatic gradients within a region is one of the characteristics of the Mediterranean region which would otherwise have a much more homogeneous climate (Lionello, 2012). Climate in the Mediterranean region is characterized by both large spatial variability and large temporal variability. The Mediterranean lies at the boundary of high-latitude atmospheric circulation and subtropical circulation, which is linked to the summer monsoon and trade wind activity (Trigo et al., 2006). The northwestern Mediterranean is under the influence of mid-latitude climate regimes, while the Asian and African monsoons, controlled by tropical and sub-tropical circulation, are more important in the central and eastern basin areas (Lionello et al., 2006). In addition to atmospheric circulation and physiography, the Mediterranean Sea is itself an important source of moisture and a heat reservoir for the region. Given these factors, the regional response to large-scale climate forcings is complex (Giorgi and Lionello, 2008). The peculiarities of the region and its response to climate change have driven intense research into Mediterranean climate over the last decade (Lionello, 2012). Future climate change can be expected to be particularly strong in this region and will likely have a marked impact on terrestrial ecosystems and on human societies. Therefore, a growing interest in the region has focused on both the study of future and past climates.

The Holocene climate and ecology of the Mediterranean is particularly well investigated, with a large amount of data including palynological, speleothem, lake isotope and lakelevel evidence (e.g. Magri and Sadori, 1999; Allen et al., 2002; Sadori et al., 2004, 2011; Zanchetta et al., 2007a, b; Colonese et al., 2011; Finne et al., 2011; Giraudi et al., 2011; Zhornyak et al., 2011; Magny et al., 2009, 2011, 2012a, b; Di Rita et al., 2013; Calo et al., 2012). These data show a complex pattern of climatic change across the Mediterranean during the Holocene, with strong spatial and temporal variability (e.g. Tzedakis, 2007; Peyron et al., 2011; Roberts et al., 2011). Recent lake-level records from Italy suggest a northsouth partitioning of Holocene climate in the central Mediterranean at $\sim 40^{\circ} \mathrm{N}$ (Magny et al., 2012b). The northern sites were characterized by summer precipitation minima during the mid-Holocene, while the southern sites (south of $40^{\circ} \mathrm{N}$ ) experience precipitation maxima at the same time. The partitioning of Mediterranean climate between the north and the south highlighted by Italian lake-level data is also apparent in the central and western Mediterranean, based on independent fire records (Vannière et al., 2011).

Recent pollen-based reconstructions of precipitation from Lakes Accesa in north-central Italy, and Pergusa in Sicily support this interpretation of a north-south climatic partition during the mid-Holocene (Peyron et al., 2011; Magny et al., 2012b). Climate reconstructions from Lake Accesa (north-central Italy) based on a multi-method approach distinguish two distinct intervals based on precipitation: the mid-Holocene is characterized by a winter precipitation maximum and a summer precipitation minimum, while the late Holocene coincides with a decrease in winter precipitation and a slight increase in summer precipitation (Peyron et al., 2011). The Lake Pergusa pollen record (southern Italy, Sicily) shows the opposite pattern: maximum winter and summer precipitation during the early to mid-Holocene and a very moderate drying trend towards modern climatic conditions during the late Holocene (Magny et al., 2012b). The Sicilian record is supported by isotopic evidence from snail shells (Colonese et al., 2011), lacustrine records (Zanchetta et al., 2007a; Sadori et al., 2008) and stalagmites (Frisia et al., 2006). The Sicilian record also shows similarities to records from the eastern Mediterranean (Bar-Matthews and Ayalon, 2011; Bar-Matthews et al., 1998; Kouli et al., 2012) and the western Mediterranean (Pérez-Obiol and Sadori, 2007).

While the records from Lakes Accesa (Tuscany) and Pergusa (Sicily) seem to support the interpretation of a northsouth climate partitioning, the scarcity of reliable palaeoclimatic records in the central Mediterranean means that new evidence is needed to validate this hypothesis. This study aims to provide robust and precise quantitative estimates of Holocene climate for the central Mediterranean region based on four high-resolution pollen records taken from lakes located along a latitudinal gradient from northern to southern Italy. Three lakes are from peninsular Italy (Lake Ledro, Lake Accesa, Lake Trifoglietti), and one is from Sicily (Lake Pergusa). We investigate climatic trends during the Holocene to test whether reconstructions from pollen records can support opposing mid-Holocene summer precipitation regimes across the north-central (minimum precipitation) and southern (maximum precipitation) Mediterranean (Magny et al., 2012b).

Special attention will be given to reconstructions of precipitation and temperature seasonality, as was the case for Lake Accesa (Peyron et al., 2011). Reconstructions of seasonal precipitation and temperature from Accesa brought new insight into the role of seasonality in this region and proposed an explanation for discrepancies between pollen, lake levels and isotope data observed in north-central Italy by invoking changes in precipitation seasonality (Peyron et al., 2011; Magny et al., 2007, 2012b). In the current study, we aim to emphasize the effects of seasonality by examining Holocene changes in precipitation seasonality across Italy. We will provide reliable quantitative estimates for seasonal climatic variables (summer and winter precipitation and temperature) from the four pollen records located in northern and southern Italy. Our purpose is to produce a climate reconstruction that can be directly compared to Peyron et al. (2011). Here too, a multi-method approach is favoured for the reconstruction to better assess the error of reconstruction inherent in pollen-based climate predictions. We have chosen four methods: the weighted averaging method (ter Braak and Van Dam, 1989), the weighted-average partial 
least-squares regression (ter Braak and Juggins, 1993), the best modern analogues technique (Guiot, 1990), and the nonmetric multidimensional scaling/generalized additive model method (Goring et al., 2009).

Changes in the regional atmospheric circulation in the Mediterranean have clear consequences for precipitation and temperature during the Holocene (Tzedakis et al., 2009; Vannière et al., 2011). Forcings such as the boreal insolation maximum (Tinner et al., 2009) and changes in the mean position of the Intertropical Convergence Zone (ITCZ) may influence the intensity and position of monsoons in the region through the position and size of Hadley cells. Thus, this study also aims to better understand which climate processes can explain the inferred climate changes and the north-south partition.

\section{Sites and data}

The core transect used in this study runs from north to south through Italy (Fig. 1), linking Lake Ledro, located on the southern slope of the Alps, to Lake Pergusa in Sicily. The sites are grouped into northern sites (Lake Ledro and Lake Accesa) and southern sites (Lake Trifoglietti and Lake Pergusa) for the purposes of most subsequent analysis. For all sites we provide information on the radiocarbon dates used in constructing the chronologies (Table 1). Site age models are described in their original publications (referenced below).

\subsection{Lake Ledro (northern Italy)}

Lake Ledro $\left(45^{\circ} 87^{\prime} \mathrm{N}, 10^{\circ} 76^{\prime} \mathrm{E}, 652 \mathrm{~m}\right.$ a.s.l. $)$ is a small lake (area: $2.2 \mathrm{~km}^{2}$, max. depth: $48 \mathrm{~m}$, catchment: $131 \mathrm{~km}^{2}$ ) in northern Italy on the southern slope of the Alps. Mean temperatures of the coldest and warmest months are $0^{\circ} \mathrm{C}$ and $20^{\circ} \mathrm{C}$, respectively, measured at Molina di Ledro, close to the lake's outlet. Annual precipitation at Molina di Ledro ranges from ca. 750 to $1000 \mathrm{~mm}$. Vegetation in the catchment is dominated by Fagus along with Abies. Higher in the Ledro Valley, the montane belt $(650-1600 \mathrm{~m})$ is characterized by Picea. The subalpine belt $(1600-2000 \mathrm{~m})$ is replaced by grasslands above $2000 \mathrm{~m}$. Lake Ledro flows into the nearby Lake Garda (65 m a.s.l). There, mild climate allows the development of a mixed oak forest with lime and elm trees, and Mediterranean vegetation such as Quercus ilex, Ericaceae and olive trees that can reach $300 \mathrm{~m}$ a.s.l. in the form of groves. More details about the site can be found in Magny et al. (2009), Vannière et al. (2013) and Simonneau et al. (2013).

A profundal master core (LL081) was built using twin cores from an undisturbed sediment zone recognized using seismic reflection. Others cores have been obtained from other locations within Lake Ledro (Ledro I, Ledro II and Ponale: Magny et al., 2012a), but only the profundal LL081 is used in this study. The chronology spans the last $17000 \mathrm{yr}$
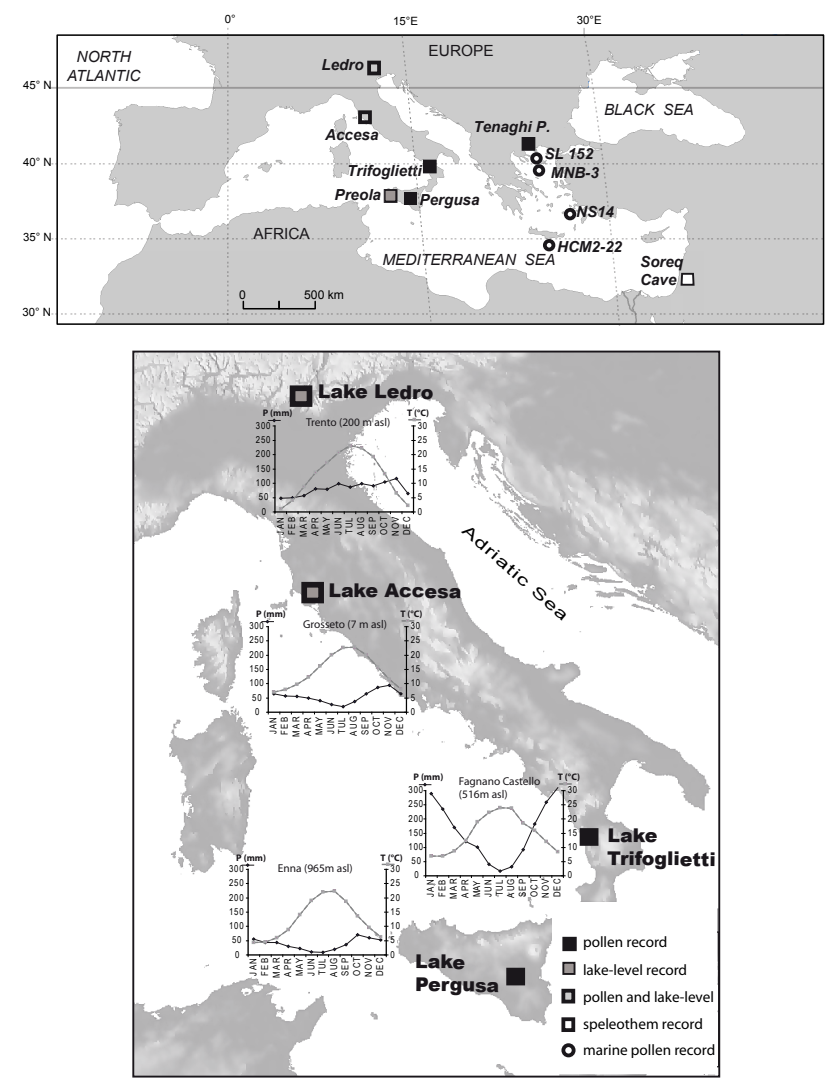

Fig. 1. Geographic location of the study sites along a latitudinal gradient from northern Italy to southern Italy: Lakes Ledro in northern Italy $\left(45^{\circ} 87^{\prime} \mathrm{N}, 10^{\circ} 76^{\prime} \mathrm{E}, 652 \mathrm{~m}\right)$, Accesa $\left(42^{\circ} 59^{\prime} \mathrm{N}\right.$, $10^{\circ} 53^{\prime} \mathrm{E}, 157 \mathrm{~m}$ ) in north-central Italy, Trifoglietti in southern Italy $\left(39^{\circ} 33^{\prime} \mathrm{N}, 16^{\circ} 01^{\prime} \mathrm{E} ; 1048 \mathrm{~m}\right)$, and Pergusa $\left(37^{\circ} 31^{\prime} \mathrm{N} ; 14^{\circ} 18^{\prime} \mathrm{E}\right.$, $667 \mathrm{~m})$ in central Sicily. Other sites mentioned in the text and ombrothermic diagrams are also plotted.

using $13{ }^{14} \mathrm{C}$ dates (Table 1 ) and 1 date from the Ledro II littoral site (Magny et al., 2012a) aligned using stratigraphic comparison. The temporal resolution is approximately estimated to $66 \mathrm{yr} / \mathrm{sample}$ throughout the Holocene (more details are given in Joannin et al., 2013).

Holocene vegetation at the site shows the development of a mixed-oak forest followed by successive expansion of trees in the montane belt and beech forest (Fig. 2). $\mathrm{Hu}-$ man land-use activity and forest exploitation begins at ca. $7500 \mathrm{cal}$ yr BP. This accelerates during the late Holocene (from 4100 cal yr BP onwards) through continuous records of anthropogenic pollen indicators and drops in arboreal pollen percentages. More details on the Lake Ledro pollen, vegetation and lake-level history are given in Joannin et al. (2013) and in Magny et al. (2009, 2012a).

\subsection{Lake Accesa (Tuscany, central Italy)}

Lake Accesa $\left(42^{\circ} 59^{\prime} \mathrm{N}, 10^{\circ} 53^{\prime} \mathrm{E}, 157 \mathrm{~m}\right.$ a.s.l.: Magny et al., 2007; Drescher-Schneider et al., 2007; Vannière et al., 2008; 
Table 1. Chronologies: information on the radiocarbon dates used for each site.

\begin{tabular}{|c|c|c|c|c|}
\hline Site & Depth $(\mathrm{cm})$ & Material & $\mathrm{AMS}^{14} \mathrm{C}$ Age BP & $\mathrm{Cal}$ yr BP $(2 \sigma)$ \\
\hline \multicolumn{5}{|c|}{ Ledro } \\
\hline & 17.5 & Wood-Peat-Charcoal & $255 \pm 30$ & $0-430$ \\
\hline & 82.6 & Wood-Peat-Charcoal & $290 \pm 30$ & $280-460$ \\
\hline & 142.6 & Wood-Peat-Charcoal & $1020 \pm 30$ & $800-1050$ \\
\hline & 193.9 & Wood-Peat-Charcoal & $1445 \pm 30$ & $1290-1390$ \\
\hline & 238.9 & Wood-Peat-Charcoal & $1945 \pm 30$ & $1820-1970$ \\
\hline & 299.5 & Wood-Peat-Charcoal & $2520 \pm 35$ & $2480-2740$ \\
\hline & 403.3 & Wood-Peat-Charcoal & $3030 \pm 35$ & $3080-3360$ \\
\hline & 462.3 & Wood-Peat-Charcoal & $4080 \pm 35$ & $4440-4810$ \\
\hline & 498.9 & Wood-Peat-Charcoal & $4550 \pm 35$ & $5050-5320$ \\
\hline & 560.4 & Wood-Peat-Charcoal & $5720 \pm 40$ & $6410-6640$ \\
\hline & 614 & Wood-Peat-Charcoal & $7270 \pm 50$ & $7980-8180$ \\
\hline & 639.5 & Wood-Peat-Charcoal & $8385 \pm 35$ & $9300-9390$ \\
\hline & 757.4 & Wood-Peat-Charcoal & $11480 \pm 60$ & $13210-13440$ \\
\hline \multicolumn{5}{|c|}{ Accesa } \\
\hline & $31-32$ & Peat & $820 \pm 35$ & $789-670$ \\
\hline & $120-121$ & Peat & $1770 \pm 35$ & $1814-1569$ \\
\hline & $219-220$ & Peat & $3000 \pm 25$ & $3322-3079$ \\
\hline & $268-269$ & Peat & $3075 \pm 30$ & $3362-3174$ \\
\hline & $305-307$ & Peat & $3355 \pm 30$ & $3687-3475$ \\
\hline & $643-644$ & Peat & $3910 \pm 30$ & $4421-4243$ \\
\hline & $739-740$ & Peat & $4675 \pm 25$ & $5568-5318$ \\
\hline & $774-775$ & Peat & $5565 \pm 35$ & $6410-6290$ \\
\hline & $823-824$ & Peat & $6330 \pm 50$ & $7415-7100$ \\
\hline & $904-905$ & Peat & $7220 \pm 40$ & $8154-7944$ \\
\hline & $906-907$ & Peat & $7235 \pm 25$ & $8156-7961$ \\
\hline & $915-916$ & Peat & $7765 \pm 40$ & $8605-8422$ \\
\hline & $920-921$ & Peat & $7580 \pm 30$ & $8411-8349$ \\
\hline & $924-925$ & Peat & $8295 \pm 35$ & $9468-9134$ \\
\hline & $935-936$ & Peat & $8610 \pm 50$ & $9697-9500$ \\
\hline & $1040-1041$ & Peat & $8830 \pm 50$ & $10154-9689$ \\
\hline & $1158-1159$ & Wood fragments & $9890 \pm 40$ & $11540-11199$ \\
\hline \multicolumn{5}{|c|}{ Trifoglietti } \\
\hline & 87 & Wood-Peat-Charcoal & $125 \pm 30$ & $0-270$ \\
\hline & 172 & Wood-Peat-Charcoal & $2675 \pm 35$ & $2740-2850$ \\
\hline & 295 & Wood-Peat-Charcoal & $3970 \pm 40$ & $4290-4530$ \\
\hline & 371 & Wood-Peat-Charcoal & $4890 \pm 35$ & $5580-5710$ \\
\hline & 497 & Wood-Peat-Charcoal & $6660 \pm 50$ & $7430-7610$ \\
\hline & 571 & Wood-Peat-Charcoal & $7920 \pm 50$ & $8600-8980$ \\
\hline & 685 & Wood-Peat-Charcoal & $8600 \pm 50$ & $9490-9680$ \\
\hline & 761 & Wood-Peat-Charcoal & $9335 \pm 60$ & $10290-10710$ \\
\hline & 806 & Wood-Peat-Charcoal & $9630 \pm 60$ & $10760-11190$ \\
\hline & 843 & Wood-Peat-Charcoal & $9850 \pm 50$ & $11190-11388$ \\
\hline & 843 & Wood-Peat-Charcoal & $9940 \pm 60$ & $11220-11690$ \\
\hline \multicolumn{5}{|c|}{ Pergusa } \\
\hline & 65 & Sediment & $1995 \pm 65$ & $1818-2127$ \\
\hline & 97 & Plant remains & $2420 \pm 97$ & $2333-2736$ \\
\hline & 192 & Sediment & $3055 \pm 75$ & $3061-3411$ \\
\hline & 245 & Sediment & $4400 \pm 105$ & $4816-5318$ \\
\hline & 317 & Sediment & $7475 \pm 65$ & $8178-8395$ \\
\hline & 369 & Sediment & $8950 \pm 90$ & $9742-10246$ \\
\hline & 378 & Sediment & $9235 \pm 95$ & $10229-10605$ \\
\hline & 456 & Plant remains & $10815 \pm 160$ & $12418-13101$ \\
\hline
\end{tabular}


Peyron et al., 2011; Finsinger et al., 2010) is a small lake (area: 16 ha, max. depth: $40 \mathrm{~m}$, catchment area ca. $5 \mathrm{~km}^{2}$ ) located in Tuscany, Italy, close to the eastern shore of the Tyrrhenian Sea, surrounded by low hills (ca. $300 \mathrm{~m}$ ). The catchment area is characterized by gentle slopes, although steeper slopes around the lake's outlet may be sensitive to the accumulation of colluvial deposits. Lake Accesa has a typically Mediterranean climate with ca. $780 \mathrm{~mm}$ annual precipitation, highest in autumn, with a marked summer drought. Mean annual temperature is ca. $13^{\circ} \mathrm{C}$, ranging from $4.5^{\circ} \mathrm{C}$ in the coldest month to $22^{\circ} \mathrm{C}$ in the warmest.

Although the Lake Accesa region is widely cultivated (cereals, vineyards and olive trees), vegetation in the region would likely be dominated by Quercus ilex (Ozenda, 1979). Existing woodland vegetation is sparsely distributed on the tops of hills, on some northern and northwestern slopes and in small shady valleys. Vegetation is characterized by open brush with Erica arborea, Arbutus unedo, Phillyrea, Pistacia, Juniperus oxycedrus, Viburnum tinus, Spartium junceum, Cistus monspeliensis, C. salviifolius or open woods with Pinus pinaster, Quercus ilex, Q. cerris, and Fraxinus ornus, depending on the frequency and intensity of human impact. The lake is surrounded by a small belt of Phragmites/Carex.

A core transect was carried out from the western shore of Lake Accesa (Peyron et al., 2011). Pollen data for the current study were extracted from two overlapping cores, $\mathrm{AC} 3$ and $\mathrm{AC} 4(\mathrm{AC} 3 / 4)$, obtained in a littoral mire, $50 \mathrm{~m}$ from the present-day lake shore. The chronology, based on $17{ }^{14} \mathrm{C}$ dates and 4 tephra layers, spans the last $11000 \mathrm{yr}$ with a temporal resolution of $85 \mathrm{yr} /$ sample (Table 1). Holocene vegetation at Lake Accesa (Fig. 2) was dominated by deciduous Quercus (probably Q. pubescens at the beginning of the Holocene) and characterized by alternating dominance of deciduous and evergreen oaks. From 9500 to $7700 \mathrm{cal} \mathrm{yr} \mathrm{BP,}$ high percentages of evergreen oaks are recorded, associated with high values of Abies (20\%). Regional Abies abundance may be overestimated from the littoral core, and may represent only local abundance since increases in Abies alba pollen recorded in the deep Lake Accesa core are small (Colombaroli et al., 2008). A persistent decline of Quercus ilex occurs around 7700 cal yr BP. The Lake Accesa core indicates human presence since the Neolithic, but cereal cultivation and pasturing becomes more pronounced at ca. 4300 cal yr BP (early Bronze Age). More details on Lake Accesa pollen, lake levels and climate history can be found in Drescher-Schneider et al. (2007), Colombaroli et al. (2008), Magny et al. (2007), Vannière et al. (2011), Finsinger et al. (2010), Sadori et al. (2011) and Peyron et al. (2011).

\subsection{Lake Trifoglietti (Calabria, southern Italy)}

Lake Trifoglietti $\left(39^{\circ} 33^{\prime} \mathrm{N}, 16^{\circ} 01^{\prime} \mathrm{E}\right.$; $1048 \mathrm{ma.s.1}$.) is a small, shallow lake (area: $0.97 \mathrm{ha}$, depth: $1.5 \mathrm{~m}$, catchment area: $0.37 \mathrm{~km}^{2}$ ) located $10 \mathrm{~km}$ from the Tyrrhenian coast in the Catena Costiera Mountains, southern Italy, near Monte Caloria (1183 m). Climate at nearby Fagnano Castello (Cosenza province) has a mean annual temperature of $15^{\circ} \mathrm{C}$, $\left(24^{\circ} \mathrm{C}\right.$ for August and $7.5^{\circ} \mathrm{C}$ for January). Despite the strictly Mediterranean latitude of the studied area, annual precipitation (including cloudiness) is high $\left(1849 \mathrm{~mm} \mathrm{yr}^{-1}\right)$, though a relatively short dry period does occur in the summer season (Joannin et al., 2012). Forest surrounding Lake Trifoglietti is dominated by Fagus with some Pinus nigra subsp. laricio. Scrub vegetation with Erica arborea and Cistus salvifolius trees develops in more open forest. Quercus cerris and Castanea sativa trees occur at lower altitude.

A core transect was carried out from the northeastern shore of the lake and pollen data were extracted from overlapping cores (Joannin et al., 2012). The chronology, based on 11 ${ }^{14} \mathrm{C}$ dates, spans the last $11500 \mathrm{yr}$ with a mean temporal resolution of $68 \mathrm{yr} /$ sample (Table 1). Holocene vegetation history at Lake Trifoglietti (Fig. 2) shows relatively stable Fagus forest during the Holocene. Prevailing westerly winds may have driven pollen taxa such as oak, hazel and other Mediterranean taxa to the site from lower vegetation belts. Changes in algae, aquatic taxa and alder proportions at Lake Trifoglietti are characteristic of changes in water depth associated with climatic change and the development of peatland at the site. The Trifoglietti pollen record shows only a weak signal of human impact, apart from those indicating pastoralism beneath forest cover. The selective exploitation of Abies appears to have been the strongest human impact in the region surrounding Lake Trifoglietti.

\subsection{Lake Pergusa (Sicily)}

Lake Pergusa $\left(37^{\circ} 31^{\prime} \mathrm{N} ; 14^{\circ} 18^{\prime} \mathrm{E}, 667 \mathrm{~m}\right.$ a.s.l.: Sadori and Narcisi, 2001; Sadori et al., 2008, 2011, 2013; Magny et al., 2012b; Zanchetta et al., 2007a) is a larger lake (area: $1.4 \mathrm{~km}^{2}$, depth: $12 \mathrm{~m}$, catchment area: $7.5 \mathrm{~km}^{2}$ ) located in central Sicily, Italy, about $5 \mathrm{~km}$ from the town of Enna. Artificial drainage and lower lake levels, associated with reduced rainfall in the region, have resulted in the progressive salinization of the lake. Records from Enna show a local mean annual precipitation between 500 and $700 \mathrm{~mm}$ and a mean annual temperature of $13.4^{\circ} \mathrm{C}$, ranging from $6^{\circ} \mathrm{C}$ in the coldest month to $24^{\circ} \mathrm{C}$ in the warmest. Potential vegetation at Lake Pergusa is mesophilous Mediterranean evergreen forest with prevailing Quercus ilex L., but the Lake Pergusa region is among the most open landscapes of Sicily, widely cultivated and dominated by xerophytic grasslands. The only traces of natural woody vegetation are sparse stands of deciduous and evergreen oaks (Quercus virgiliana, $Q$. ilex, $Q$. pubescens, $Q$. suber and Rhamnus alaternus).

Pollen records have been obtained from two different locations within Lake Pergusa: a $4.5 \mathrm{~m}$ long core (PRG1) provided a record from $12500 \mathrm{cal}$ yr BP to the present (Sadori and Narcisi, 2001), while a second core (PG2) spans an interval from $6700 \mathrm{cal}$ yr BP to the present (Sadori et al., 

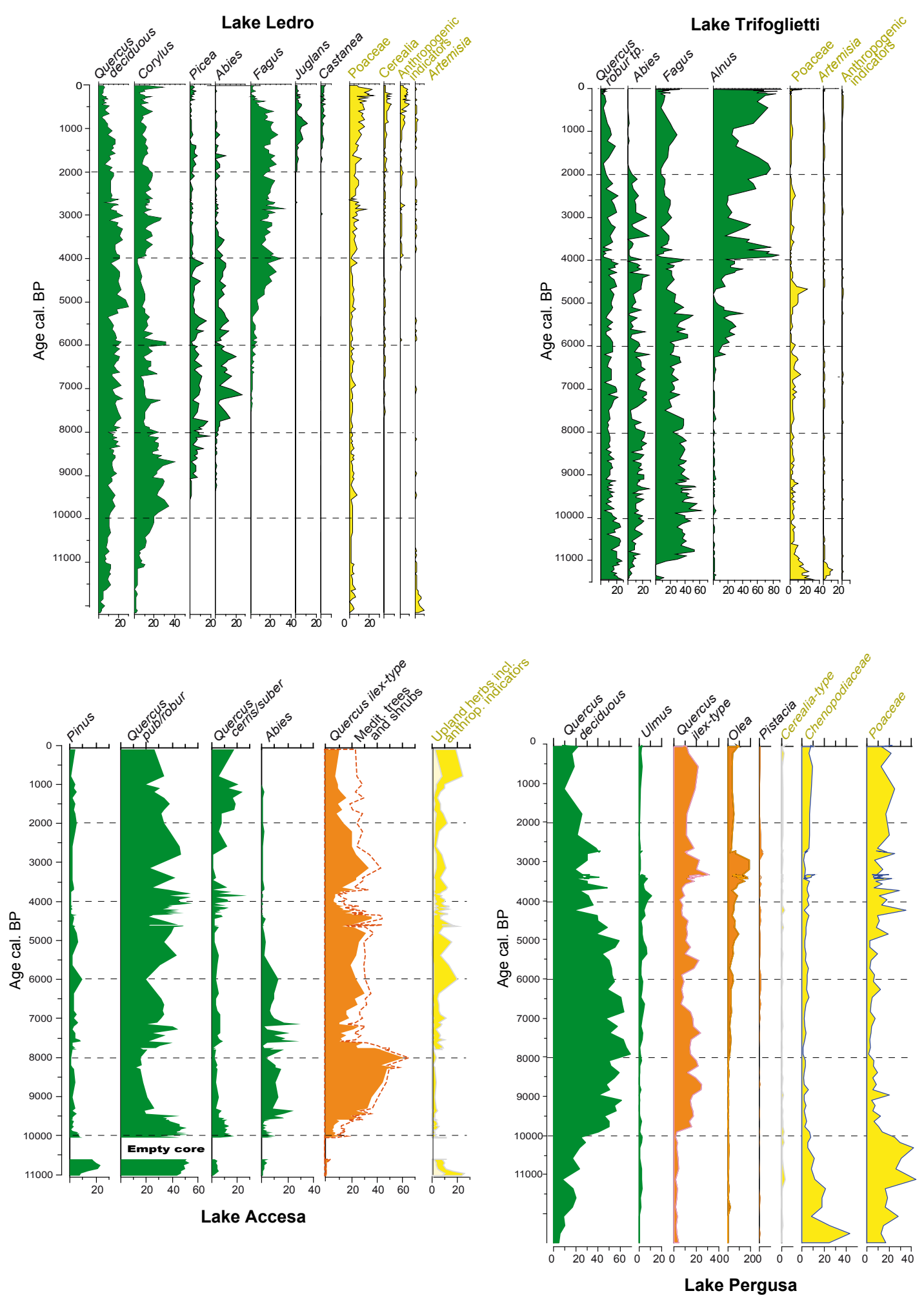

Fig. 2. Simplified pollen diagrams for the following: Lake Ledro deep core "LL081" (Joannin et al., 2013), Lake Accesa littoral core "AC3/4" (Drescher-Schneider et al., 2007), Lake Trifoglietti (Joannin et al., 2012) and Lake Pergusa (Sadori and Narcisi, 2001). The chronology of the four pollen records is based on radiocarbon dates compiled in Table 1. More details on each chronology are given in the references papers. 
2013). Results from the PRG1 pollen record have been extensively reported (Sadori and Narcisi, 2001; Sadori and Giardini, 2007; Sadori et al., 2011; Magny et al., 2011). The PRG1 core is used in this study since it covers the entire Holocene (for more details on late Holocene vegetation and climate history based on the PG2 record, see Sadori et al., 2013). The chronology, based on $8{ }^{14} \mathrm{C}$ dates and 1 tephra layer, provides a mean temporal resolution of $131 \mathrm{yr} / \mathrm{sample}$ throughout the Holocene (Table 1). Holocene vegetation history (Fig. 2) shows that deciduous and evergreen oaks dominated from 10000 to $5000 \mathrm{cal} \mathrm{yr} \mathrm{BP}$ (Sadori et al., 2011). Tree cover declined briefly from ca. 8900 and 8700 cal yr BP. Soon after $8000 \mathrm{cal} \mathrm{yr} \mathrm{BP,} \mathrm{Olea} \mathrm{begins} \mathrm{to} \mathrm{increase,} \mathrm{indicat-}$ ing the beginning of a climatic trend towards more arid conditions. Forested landscape around Pergusa opened at ca. 5500-5000 cal yr BP (Sadori et al., 2013). Although ancient pre-Greek, culturally evolved, civilizations were present in southern Italy since the early Holocene, agricultural activities indicated by Secale, Linum and Vitis pollen are only recorded at Pergusa after $5000 \mathrm{cal}$ yr BP. Human activities become more marked at $3000 \mathrm{cal} \mathrm{ky} \mathrm{BP}$, and increase significantly over the last millenia. The landscape, as indicated by pollen, over the last millenia is clearly influenced by human impact more so than by climate with clear increases in olive tree, walnut, chestnut and cereal cultivation (Sadori et al., 2013).

\section{Climate reconstruction methods}

Individual pollen-based climate reconstruction methods have their own set of advantages and limitations (Birks and Birks, 2006; Brewer et al., 2008; Birks et al., 2010). For this reason we adopted a multi-method approach that would allow us to better assess reconstruction error and provide more precise and robust climate estimates than those based on only one method (e.g. Klotz et al., 2003; Peyron et al., 2005, 2006; Kühl et al., 2010). Such an approach has been successfully tested for the Holocene from Mediterranean marine and terrestrial pollen records (Dormoy et al., 2009; Peyron et al., 2011, although see Birks et al., 2010). We chose four methods, including most standard methods, and based on different ecological concepts. Here, the modern analogue technique (MAT: Guiot, 1990), the weighted averaging method (WA: Ter Braak and Van Dam, 1989), the weightedaverage partial least-squares regression (WAPLS: Ter Braak and Juggins, 1993), and the non-metric multidimensional scaling/generalized additive model method (NMDS/GAM: Goring et al., 2009) are used. The WA, WAPLS and the NMDS/GAM are true transfer functions based on a calibration between environmental variables and modern pollen assemblages, whereas the MAT does not require real calibration and is based on a comparison of past assemblages to modern pollen assemblages. For all the methods presented here, we use the modern pollen dataset developed by Dormoy et al. (2009), containing more than 2000 samples from the Mediterranean region with climate estimates for sites developed by New et al. (2002). To improve reconstruction, we have updated the dataset by adding 26 modern surface samples from around Lake Trifoglietti (Joannin et al., 2012), Mount Altesina close to Lake Pergusa (Sicily) and Lake Preola (Sicily).

\subsection{MAT}

MAT reconstructs past climate parameters by considering proportion of pollen assemblages (Overpeck et al., 1985; Guiot, 1990). The MAT uses the squared-chord distance, effective with percentage data, to determine the degree of similarity between samples with known climate parameters (modern pollen samples) to a sample for which climate parameters are to be estimated (fossil pollen sample). The smaller the chord distance is, the greater the degree of analogy between the two samples. To calculate the climate parameters for each fossil sample it is common practice to calculate the climate parameters as the weighed mean of the present-day climate of the closest $n$ modern samples or "analogues". A minimum "analogue" threshold is often established beforehand using a Monte Carlo method. Finally, the palaeoclimate is reconstructed by weighted averaging using modern climate data, here from New et al. (2002).

\subsection{WA}

The WA method (ter Braak and van Dam, 1989) is a transfer function that uses the (implied) unimodal responses of pollen taxa (in this case) along environmental gradients to infer climate by weighting taxon abundances from target assemblages using the calibrated optima. While the assumption of unimodality is, in practice, violated by a large number of pollen taxa (see figures in Williams et al., 2006), Birks et al. (2010) have described the ways in which the strengths of WA might outweigh some of its limitations, accounting for its popularity in many modern studies.

\subsection{WAPLS}

WAPLS is a "classic" regression method which also assumes that the relationships between pollen percentages and climate are unimodal: each taxon grows best at a particular optimal value of an environmental variable and cannot survive when the value of that variable is too low or too high. If taxon ecology can be assumed to be constant through time, then, even if the overall pollen assemblage has no modern analogue, a reasonable reconstruction can be given. WAPLS operates by compressing the overall data structure onto latent variables. The modern pollen dataset used may be considered a large multidimensional matrix. Since there is some co-linearity among pollen taxa, and since some taxa will be related to climate parameters of interest, it is possible to reduce the dataset into a smaller number of components based 
on both linear predictors of the parameter of interest and the residual structure of the data when those predictors are removed. The modification of PLS proposed by ter Braak and Juggins (1993) requires transformation of the initial dataset using weighted averaging (ter Braak and van Dam, 1989) along a gradient defined by the climate parameter of interest, such that the pollen taxa that best define the climate gradient are weighted more heavily than those that show little specificity to the gradient.

\subsection{NMDS/GAM}

This method, first developed from pollen assemblages in British Columbia, Canada (Goring et al., 2009), has recently been successfully tested on Mediterranean pollen assemblages (Dormoy et al., 2009; Peyron et al., 2011). This method begins by reducing the dimensionality of the dataset using non-metric multidimensional scaling, a non-parametric ordination method that retains the dissimilarity structure of the data to generate low-dimensionality representations. In this way it is somewhat similar to the MAT, although the ordination recovers not only the degree of dissimilarity between samples, but also the direction of dissimilarity. Once the lowdimensionality representation is generated, the NMDS/GAM method fits a generalized additive model to the ordination space to reconstruct the climate parameter of interest. Since this method uses non-parametric methods, specific statistical violations, such as the non-linearity of the relationship between climate parameters and pollen taxa, may be avoided.

\subsection{Validation of the methods and error calculation}

To some degree all methods are subject to error resulting from "noise" in the dataset. This noise may result from variation in basin characteristics, co-variance of climate variables, differential degradation of pollen taxa resulting from the deposition substrate, differences in pollen transport and local anthropogenic effects. The ecological noise is internalized differently in each pollen-based reconstruction method, although overlap exists among more closely related methods (e.g. effects of spatial autocorrelation: Telford and Birks, 2005; effects of sample depositional environments: Goring et al., 2010). In general, as noise in the pollen dataset increases, model error increases. But as dataset size increases, many models become more robust (Birks et al., 2010). More details on the validation procedure used for pollen-climate calibration with the European pollen dataset are given in Peyron et al. (2011).

Non-climatic factors may also affect pollen assemblages during the Holocene. Human impacts in particular have affected the natural vegetation of the Mediterranean since $\sim 7500$ cal yr BP, but disentangling climatic and anthropogenic causes of vegetation change is complex. For example, both human activity and climate may have resulted in the apparent aridification in Sicily and across the Mediterranean
Basin at 3500 cal yr BP (Sadori et al., 2013). While pollen records may be susceptible to change from anthropogenic effects, previous studies show that human impacts on Mediterranean vegetation (using pollen as a proxy) are often hard to detect prior to the Bronze Age (Sadori et al., 2011; Mercuri et al., 2012). While human influences in the last 3000 cal yr BP are non-negligible, an unequivocal, widespread human signature in this region only begins in the Roman period. Given this, it is likely that human impacts may influence pollenbased climate reconstruction, but the precise nature of these biases is difficult to assess due to a lack of pollen and climate data from "undisturbed" vegetation. Regardless of the extent of human influence, pollen-based climate reconstructions appear to show robust results through time, particularly when other proxy data from stable isotopes, speleothems, tree rings or lake levels are used. Thus, we combine a multi-model approach for pollen reconstructions with data from multiple proxies to provide broader support for our findings.

\section{Results and discussion}

Quantitative climate reconstructions for each pollen sequence were performed for summer and winter temperature in Fig. 3, and summer and winter precipitation in Fig. 4 to emphasize changes in seasonality.

\subsection{A north-south climatic pattern? Looking at the temperature reconstruction}

Climate reconstructions suggest the partitioning of Holocene summer temperature regimes between northern (Lakes Ledro and Accesa) and south-central (Lakes Trifoglietti and Pergusa) Mediterranean sites (Figs. 3 and 5). Northern sites show warm conditions during the early to mid-Holocene, while cool conditions in Sicily are reconstructed during the same time period. This pattern reverses in the late Holocene, with southern sites warming and northern sites cooling. The partitioning of temperature trends is evident when results are expressed as anomalies (Fig. 5). Pollen-inferred temperatures from Lake Ledro (north) show two distinct periods: relatively high temperatures before $7200 \mathrm{cal} \mathrm{yr} \mathrm{BP}$ that are followed by a summer cooling trend from $7000 \mathrm{cal}$ yr BP to 4600 cal yr BP. Pollen-inferred temperatures from Lakes Trifoglietti and Pergusa (south; Figs. 3 and 5) show two distinct periods of temperature. Lake Ledro shows the opposite pattern, with cold temperatures before 6400-7000 cal yr BP, followed by an abrupt change towards warm summer conditions from $6400 \mathrm{cal}$ yr BP to the present.

This pattern of climate partitioning between the north and the south is similar to partitioning in the eastern Mediterranean, particularly in the northern and southern Aegean Sea (Dormoy et al., 2009; Kotthoff et al., 2008, 2011). The climate pattern observed in northern Italy from Lake Ledro (warm early to mid-Holocene followed by a summer cooling 

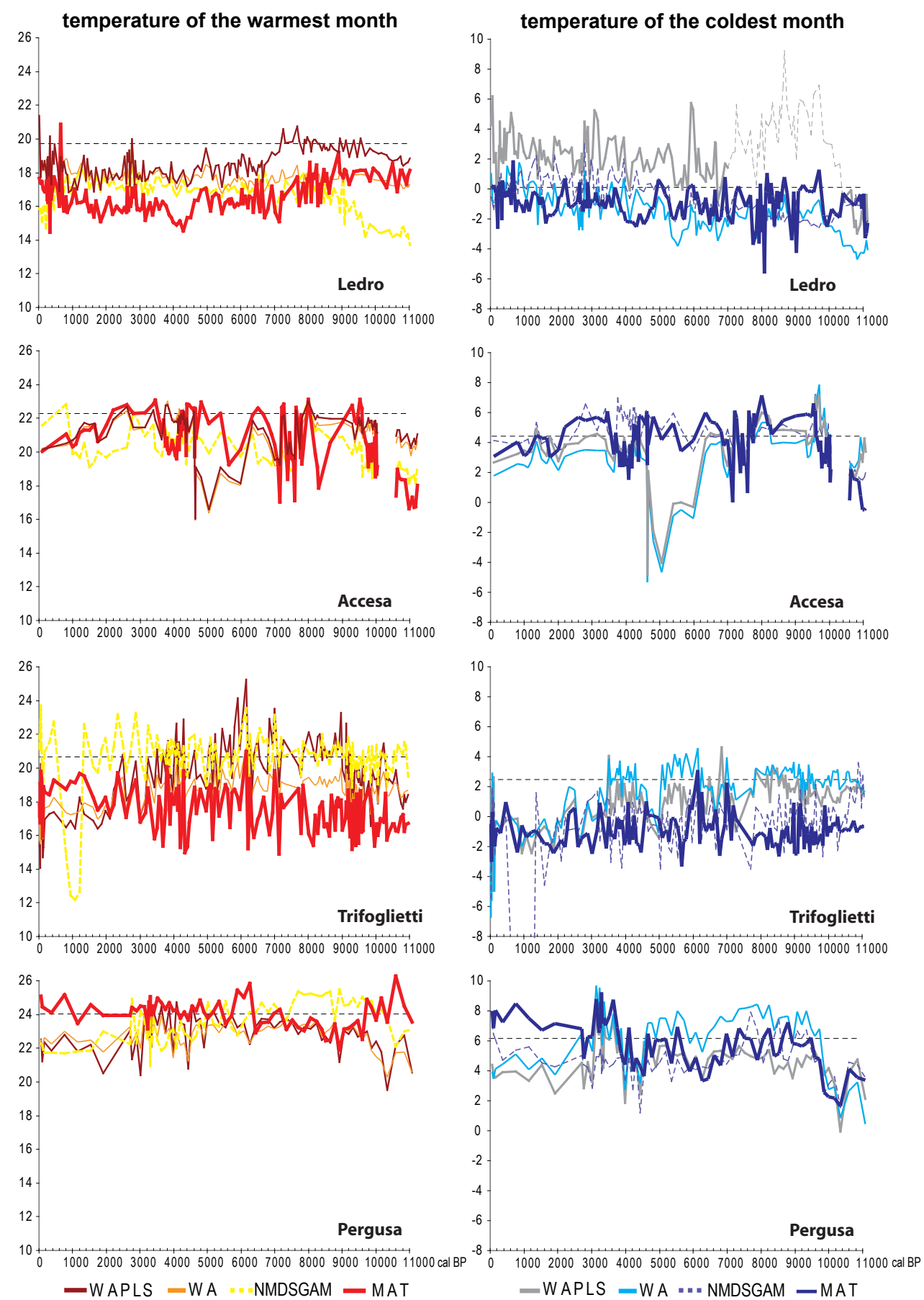

Fig. 3. Pollen-based temperatures (warmest and coldest month). Climate values are estimated using four methods: the modern analogue technique (MAT), the non-metric multidimensional scaling/generalized additive model method (NMDS/GAM), weighted averaging (WA), and weighted-average partial least-squares regression (WAPLS).

Modern values are indicated with a horizontal dotted line. The thin dotted grey curve (temperature of the coldest month, Ledro) corresponds to unrealistic values.

trend after $7200 \mathrm{cal}$ yr BP) is similar to a pollen-based climate reconstruction from the northern Aegean Sea (marine core SL52, Fig. 5d: Dormoy et al., 2009). Further to the north, the Tenaghi Philippon (Greece) pollen-based temperature reconstruction (Fig. 5c) also provides evidence of high early
Holocene temperatures declining to the mid-Holocene (Pross et al., 2009). Moreover, Kouli et al. (2012) use a temperature index based on the ratio of cool to warm-temperate broadleaved taxa to show a Holocene summer temperature regime with strong differences between the northern and 

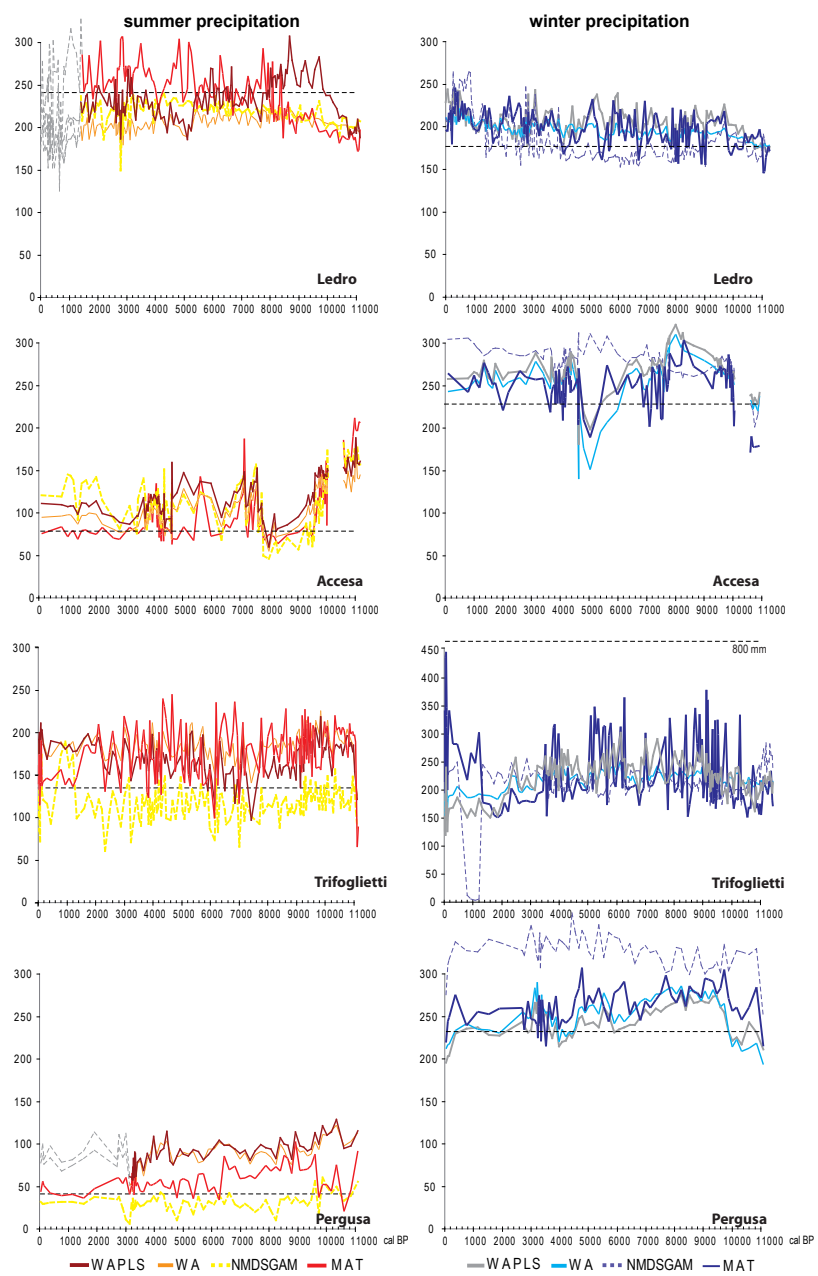

Fig. 4. Pollen-based seasonal precipitation (winter $=$ sum of December, January, February precipitation, and summer = sum of June, July, August precipitation, in $\mathrm{mm}$ ) values for the four lakes estimated with the methods listed in Fig. 3. Modern values are indicated with a horizontal grey dotted line. The thin dotted grey curve (summer precipitation, Ledro and Pergusa) corresponds to unrealistic values.

southern Aegean Sea based on three cores from the region. The north (core MNB3) is marked by warm conditions during the early to mid-Holocene, while the south (core NS14) remains cool. Following 6500-7000 cal yr BP, the pattern appears to reverse, with cold conditions in the north culminating around $4500 \mathrm{cal} \mathrm{yr} \mathrm{BP}$, while warm conditions exist in the south. The northern temperature index fits with the summer cooling trend reconstructed from Lake Ledro (Fig. 5a and e), while the temperature index from the southeastern Aegean fits with the warming trend reconstructed from Lakes Accesa, Trifoglietti and Pergusa pollen data (Fig. 5d-g). The pattern of warm early to mid-Holocene temperatures and cooler late Holocene climate in the north is supported by alkenone-based SST curves from both records (Gogou et al., 2007; Triantaphyllou et al., 2009b). Alkenone-derived
SSTs range between $20^{\circ}$ and $23^{\circ} \mathrm{C}$ in the North Aegean MNB3 record during the early to mid-Holocene and drop to $20^{\circ} \mathrm{C}$ after $6000 \mathrm{cal} \mathrm{yr} \mathrm{BP}$ (Gogou et al., 2007). In contrast, the South Aegean record of core NS14 displays SSTs ranging from $17^{\circ}$ to $22^{\circ} \mathrm{C}$ for the early to mid-Holocene, rising to $\sim 24.8^{\circ} \mathrm{C}$ at about $5000 \mathrm{cal} \mathrm{yr} \mathrm{BP}$ (Triantaphyllou et al., 2009b). Terrestrial biomarkers ( $n$ alkanes) indicate the dominance of warm species in the South Aegean during the mid- to late Holocene, confirming the pollen signal (Kouli et al., 2012) and agreeing with our pollen-based reconstructions. Even at a regional scale, the Holocene climate signal reconstructed at Lakes Accesa, Trifoglietti and Pergusa fits with the summer temperature trend over Southern Europe (south of $45^{\circ} \mathrm{N}$, ), reconstructed by Davis and Brewer (2009) in Fig. 5f-h.

\subsection{A north-south climatic pattern? Looking at the precipitation reconstruction}

Pollen-inferred precipitation from Lakes Ledro and Accesa in the north, and Trifoglietti and Pergusa in the south, suggests a partitioning of the precipitation regime between the North and South Mediterranean during the Holocene (Figs. 4, 6 and 7). Relatively dry conditions in summer characterize the Lake Ledro record from 11500 to 8500 cal yr BP, while precipitation in southern Italy and Sicily reaches a maximum (Figs. 4 and 6). Pollen-inferred precipitation increases at Lake Ledro from $8200 \mathrm{cal}$ yr BP to $4000 \mathrm{cal} \mathrm{yr} \mathrm{BP,} \mathrm{reach-}$ ing a maximum from 4000 cal yr BP to the present. The inferred climate from Lakes Trifoglietti and Pergusa in the south differs from Lake Ledro, showing two distinct periods of precipitation change: with wet conditions prior to $6500 \mathrm{cal}$ yr BP, followed by a trend towards dryer conditions from $6500 \mathrm{cal} \mathrm{yr} \mathrm{BP}$ to 4500 , and a period post $4000 \mathrm{cal} \mathrm{yr} \mathrm{BP}$ with dry conditions.

A contrasting pattern between the northern and southern Mediterranean is also apparent in winter precipitation, even if relatively moist winter conditions seem to characterize the four sites' areas during the Holocene (Fig. 4). The winter and summer precipitation trends reconstructed at Lake Ledro fit well; winter precipitation increases from $10000 \mathrm{cal} \mathrm{yr} \mathrm{BP}$ to 4000 cal yr BP, reaching a precipitation maximum from 4000 to the present, similar to the summer precipitation record. Lake Trifoglietti presents a problematic reconstruction, much below modern winter precipitation values for all methods, possibly due to specific aspects of its location (Joannin et al., 2012). Although reconstructed precipitation values at Lake Trifoglietti are low, we are still able to reconstruct a precipitation trend that fits well with Pergusa and Accesa, showing a "Holocene Optimum" between 9500 and 5000 cal yr BP followed by a trend towards aridification. At Trifoglietti, the two periods marked by high precipitation at $\sim 7200-6500$ and 4900-4500 cal yr BP (Fig. 6) are almost synchronous with phases of high fluvial activity and floods recorded at 7200 6800 and $4800-4550$ cal yr BP in nearby Basilicata, southern 
a)

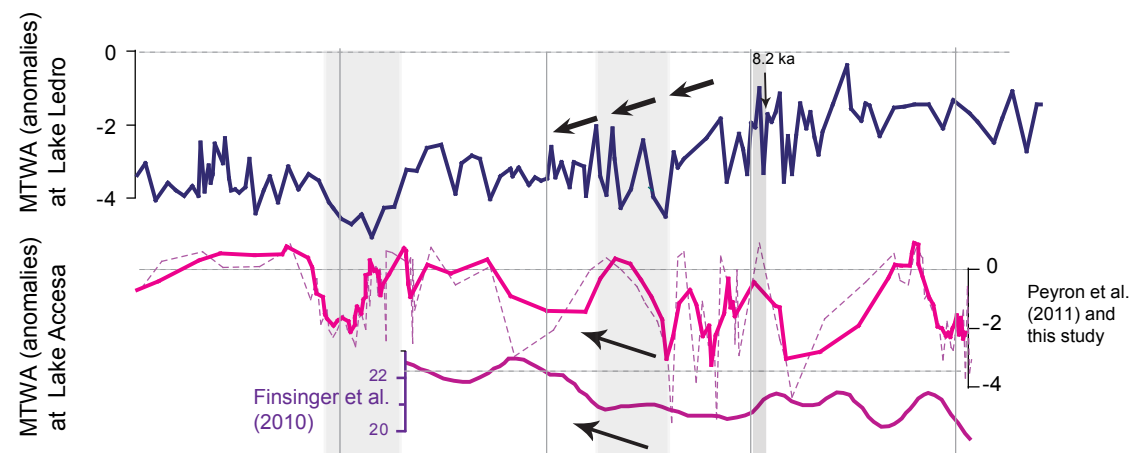

c)

过

d)

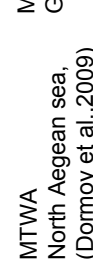

e)

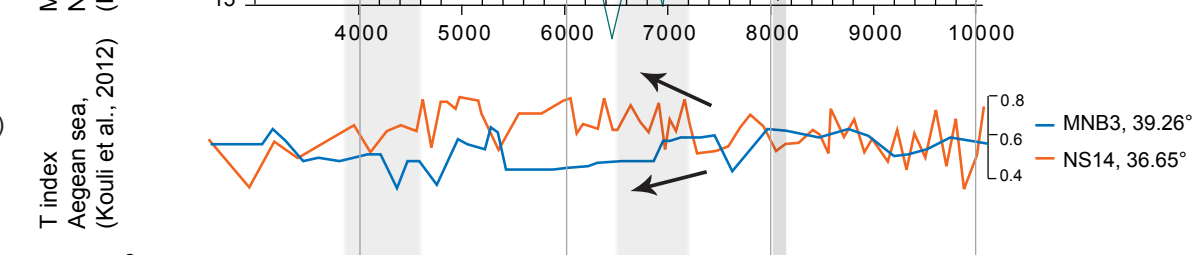

f)

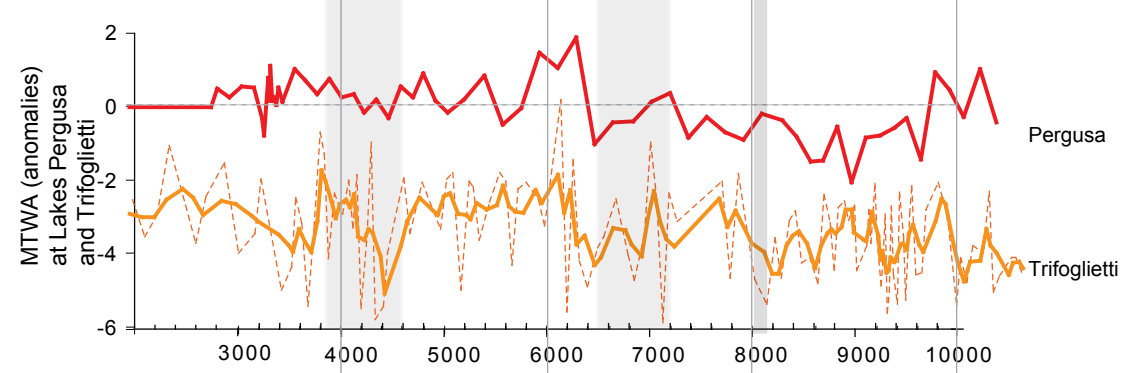

h)
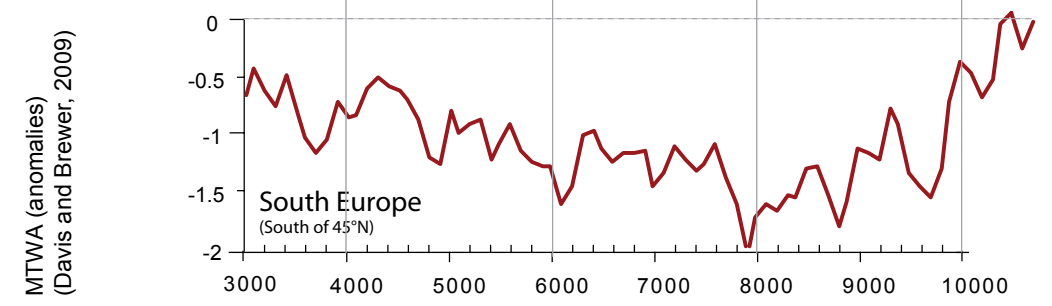

Age cal yrs BP

Fig. 5. Synthesis figure for selected Mediterranean temperature records. (a) Pollen-inferred temperature of the warmest month for Lake Ledro (as for Fig. 3), MAT only. (b) Pollen-inferred temperature of the warmest month for (1, pink curve) Lake Accesa littoral core, MAT only (as for Fig. 3), and (2, purple curve) Lake Accesa profundal core, WAPLS only (Finsinger et al., 2010). (c) Pollen-inferred temperature of the warmest month for Tenaghi Philippon, Greece, MAT only (Pross et al., 2009). (d) Pollen-inferred temperature of the warmest month for the marine core SL152, Aegean Sea, (Dormoy et al., 2009) with three methods (short dotted line: MAT; blue line: PLS; long dotted line: NMDS/GAM). (e) Pollen-based temperature index "T index" for the marine cores MNB3 (North Aegean Sea), and NS14 (South Aegean Sea), (Kouli et al., 2012). (f) Pollen-inferred temperature of the warmest month for Lake Pergusa (as for Fig. 3), MAT only. (g) Polleninferred temperature of the warmest month for Lake Trifoglietti (as for Fig. 3), MAT only; the curve of temperature is calculated with a moving average (bold curve) and raw values are also plotted (dotted curve). (h) Reconstruction of temperatures of the warmest month (anomalies) for Southern Europe based on pollen data from over 500 pollen sites from across Europe, MAT only (Davis and Brewer, 2009; Davis et al., 2003). 


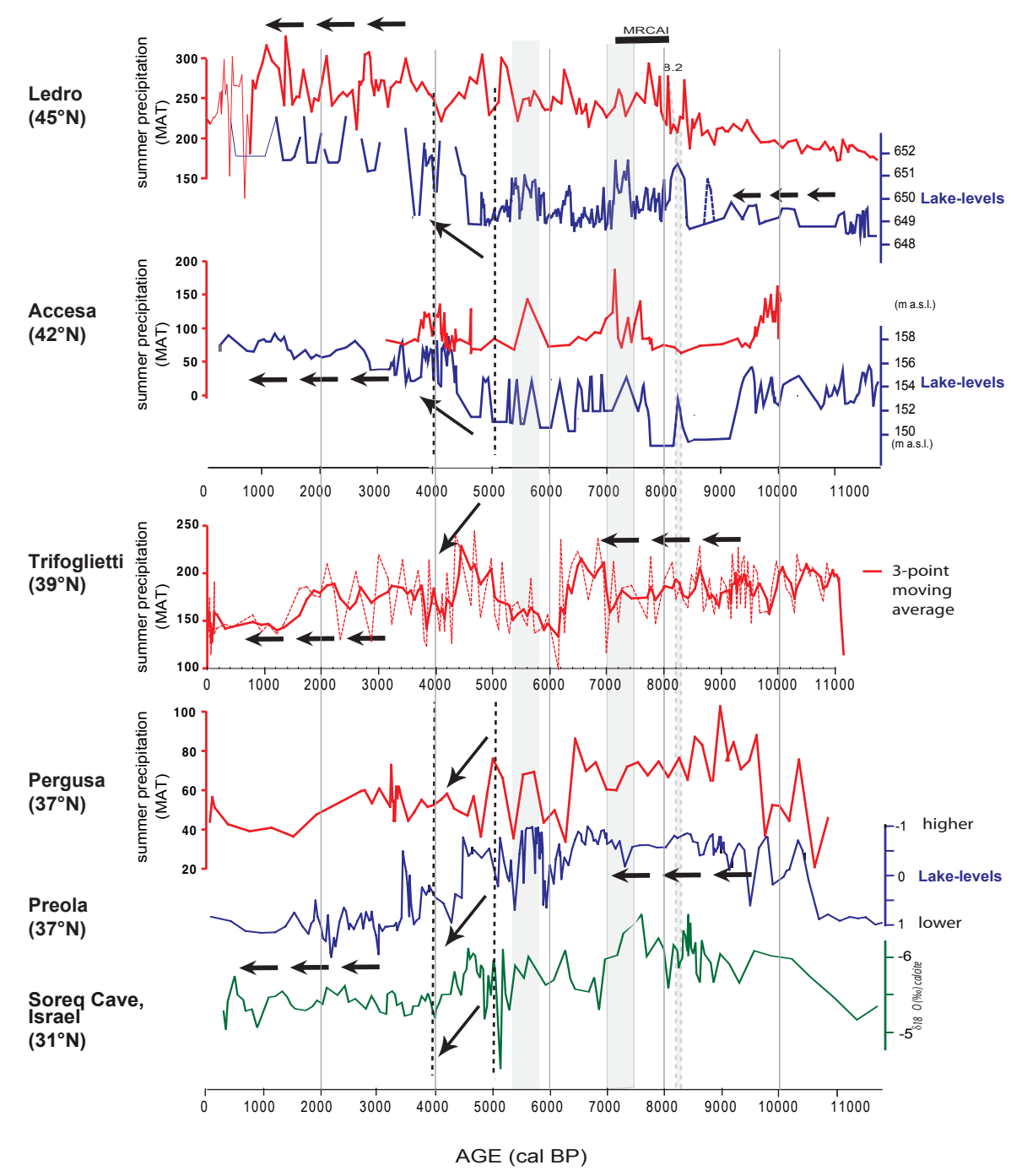

Fig. 6. Comparison between pollen-inferred summer precipitation (MAT only) and lake-level variations at Lakes Ledro, Accesa, Trifoglietti and Pergusa. More details on the lake-level data are given in Magny et al. (2012a) for Lake Ledro, Magny et al. (2007) for Lake Accesa, and Magny et al. (2011) for Lake Preola (Sicily). Oxygen isotope data based on speleothem from Soreq Cave, Israel, is also plotted for comparison with eastern Mediterranean sites (Bar-Matthews and Ayalon, 2011; Bar-Matthews et al., 1998; Vaks et al., 2006). MRCAI=period of maximal rate of change in annual insolation.

Italy (Piccarreta et al., 2011). The correlation between the precipitation reconstruction and independent assessments of hydrological activity may indicate that, while the reconstruction values may be offset strongly at Lake Trifoglietti, the anomaly trends are consistent with long-term change in regional precipitation.

One goal of this study is to test the hypothesis proposed by Magny et al. (2012b) that mid-Holocene summer precipitation regimes are partitioned and that north-central and southern Mediterranean patterns of change are in opposition to one another. This assumption is based on lake-level variations established for Italy from carbonate concretions produced during summer (Magny et al., 2011). Figure 6 shows a direct comparison between independent Holocene lake-level changes and the pollen-inferred summer precipitation for Lakes Ledro and Accesa. Summer precipitation estimated for the southern Lakes Trifoglietti and Pergusa are compared to the Lake Preola lake-level reconstruction from coastal Sicily (Fig. 6; Magny et al., 2011). The lake-level and pollenbased climate reconstructions both suggest climatic partitioning during the Holocene. These opposing patterns appear (1) during the early to mid-Holocene, when the northern sites (Ledro, Accesa) are characterized by a minimum in summer precipitation and associated lake-level minimum, while the sites located south of ca. $40^{\circ} \mathrm{N}$ (Trifoglietti, Pergusa) are marked by high precipitation and associated high lake levels and (2) during the late Holocene when pollen-inferred precipitation and lake-level reconstructions indicate maxima 
in northern Italy and minima in the south. These findings are further supported by a synthesis of fire activity for the Mediterranean Basin (Vannière et al., 2011). Low fire activity was observed in the southern Mediterranean (south of $40^{\circ} \mathrm{N}$ ) during the mid-Holocene (ca. 7500-4500 cal yr BP), while northern Mediterranean records suggest a contemporaneous increase in fire activity. The north-south climatic partition in Italy highlighted in our study is also apparent in the central and western Mediterranean from independent fire records (Vanniere et al., 2011). Relatively abrupt changes in fire activity are observed ca. 5500-5000 cal yr BP, at approximately the same time as the climate transition recorded ca. $5000 \mathrm{cal}$ yr BP by the lake-level and summer precipitation records from Italy (Fig. 6).

The climate trend observed in southern Italy and Sicily shows strong similarities to the Soreq Cave speleothem record (Israel; Bar-Matthews et al., 1998) from the eastern Mediterranean (Magny et al., 2012b, Fig. 6). A similar climate pattern also exists from records in the Aegean Sea (Fig. 7) based on (1) a relative "humidity index" established from the three marine pollen records located across a northsouth transect in the Aegean Sea (Kouli et al., 2012), and (2) the pollen-based climate reconstruction from marine core SL52 located in the North Aegean Sea (Dormoy et al., 2009). The humidity index (Fig. 7) shows a climatic partition during the Holocene that matches well with the pollen-based precipitation reconstructions: the mid-Holocene is characterized by dry summer conditions in northern Italy and the North Aegean Sea, while wet conditions are reconstructed in southern Italy, Sicily and South Crete. Warm and humid conditions that prevailed during the mid-Holocene are also apparent in the South Aegean marine NS14 record by the deposition of a distinguishable sapropel-like layer (Sapropel midHolocene: SMH, Triantaphyllou et al., 2009b). The trend of warm and humid conditions in the south reverses during the late Holocene, after 6000 cal yr BP.

A shift in climate at ca. 4500 cal yr BP is clear from summer precipitation, lake-level and speleothems records from the region (Fig. 6). This shift is also seen in the eastern Mediterranean by Finné et al. (2011). Palaeoclimate records in the eastern Mediterranean reconstruct wet conditions from 6000 to 5400 cal yr BP followed by a period of drying that develops into aridity by ca. 4600 cal yr BP. Climate changes around 4500 cal yr BP may have resulted from large-scale changes in the atmospheric circulation affecting the southern Mediterranean area over the mid- to late-Holocene transition (Magny et al., 2009). Changes could be linked to a non-linear response of the climate system to the gradual decrease in insolation in addition to other key seasonal and interhemispherical trends related directly to changes in insolation.

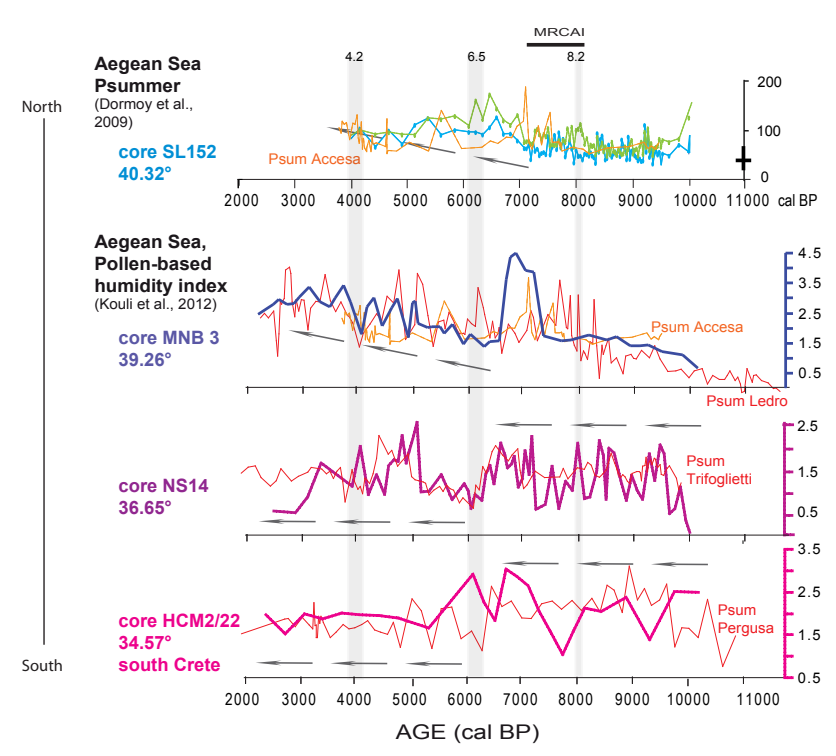

Fig. 7. Contrasting precipitation patterns in Italy and in Aegean Sea during the Holocene. Psum = Psummer (MAT only) as in Fig. 4, from each lake pollen record (dotted orange: Accesa; red: Ledro, Trifoglietti and Pergusa; units same as Fig. 6).

Comparison with the Aegean Sea records. (1) Pollen-inferred summer precipitation (in $\mathrm{mm}$ ) for the marine core SL152, North Aegean Sea (Dormoy et al., 2009), obtained with the PLS method (green curve), and the NMDS/GAM (blue curve); (2) pollen-based humidity index established by Kouli et al. (2012) from three marine pollen records located across a north-south transect in the Aegean Sea: cores MNB3 (blue curve), core NS14 (purple curve) and core HCM2/22 (dark pink curve). Short events at around 8200, 6500 and $4200 \mathrm{cal}$ yr BP are also plotted. MRCAI = period of maximal rate of change in annual insolation.

\subsection{Short-term events around 8000,6500 and 4200 cal yr BP}

Short-term Holocene climate events are evident in the polleninferred climate reconstruction for Lakes Ledro and Trifoglietti (and to a lesser extent at Lake Pergusa). These shortlived events occur at ca. 8000, 6500 and $4200 \mathrm{cal} \mathrm{yr} \mathrm{BP}$ and they correspond to strong shifts in the humidity index reconstructed from the Aegean cores.

The earliest event seems to correspond with the regional expression of the $8.2 \mathrm{kyr}$ event (Alley et al., 1997) in the Mediterranean region (Magny et al., 2003, 2007; Kotthoff et al., 2008, 2011; Pross et al., 2009; Triantaphyllou et al., 2009 b). This event is commonly explained through atmospheric circulation changes induced by freshwater pulses that produced a weakening of the thermohaline circulation in the North Atlantic. This allowed an expansion of the Eurasian/Siberian High, ultimately resulting in colder and drier winters (Renssen et al., 2002; Rohling et al., 2002). The multi-method approach for Lake Ledro indicates a winter temperature drop $>3{ }^{\circ} \mathrm{C}$ (Fig. 3) and a summer temperature decrease of $1.5^{\circ} \mathrm{C}$ (Figs. 3 and 5). This strong cooling is 
corroborated by the $\sim 4{ }^{\circ} \mathrm{C}$ abrupt winter cooling evidenced in Tenaghi Philippon from pollen data (Pross et al., 2009; Peyron et al., 2011), and by pronounced cooling between 8200 and $7800 \mathrm{cal} \mathrm{yr} \mathrm{BP}$ in the northern Aegean based on alkenone data (Gogou et al., 2007). Summer cooling also occurs at Tenaghi Philippon (Pross et al., 2009) and in the North Aegean Sea core SL152 (Fig. 5a and b; Dormoy et al., 2009). Dry winters and wet summers reconstructed using the Lake Ledro core (Figs. 4, 6 and 7) fit well with wet summer conditions reconstructed from the SL152 marine core in the northern Aegean Sea (Fig. 7). At Accesa, the $8.2 \mathrm{kyr}$ event is marked by a well-identified lithological change but is weakly expressed in the pollen-based reconstruction (Fig. 4). However, wet summer conditions around this time period can be seen with the multi-method approach (Fig. 4), associated with a short-term lake-level rise centred at $8200 \mathrm{cal} \mathrm{yr} \mathrm{BP}$ (Fig. 6) and a decline in the fire regime (Vannière et al., 2008), also suggesting wet conditions.

There is no clear hydrological signal for the $8.2 \mathrm{kyr}$ event in southern Italy obtained from the Lake Trifoglietti reconstruction, although lower summer temperatures $\left(-2{ }^{\circ} \mathrm{C}\right.$, Figs. $3 \mathrm{a}$ and $5 \mathrm{~g}$ ) and dry summer conditions are suggested (Fig. 6). The $8.2 \mathrm{kyr}$ event signal from Pergusa is very weak but seems to correspond to dry summer conditions at $\sim 8300$ cal yr BP associated with a $1.5^{\circ} \mathrm{C}$ decline in summer and winter temperature (Fig. 3). Although the signal of short-term change is weak in southern Italy, the broader changes in climate seem to confirm the hypothesis by Magny et al. (2003) of a hydrological partition in Central Europe for the $8.2 \mathrm{kyr}$ event, with Southern Europe marked by dry climate and northern latitudes (from ca. $43-50^{\circ} \mathrm{N}$ ) marked by wet conditions. Similarly, the $8.2 \mathrm{kyr}$ event does not seem to show either cold or dry conditions in the southern Aegean Sea relative to more northern sites, although a drop in precipitation is recorded (Triantaphyllou et al., 2009b).

The second short-lived cool and dry event at ca. $6500 \mathrm{cal} \mathrm{yr} \mathrm{BP}$ is recorded in the pollen reconstructions for Lakes Trifoglietti and Pergusa (Fig. 5). The cooling and drying at the two core sites corresponds remarkably well to a number of independent studies from the region. At ca. 6500 terrestrial biomarkers from marine cores in the Aegean Sea reflect less humid conditions and a "cooler" vegetation type, supported by pollen from the same marine cores (Fig. 7; Kouli et al., 2012). This cool-dry event is also characterized by a strong decrease in SST and the termination of the S1 sapropel in the southern Aegean Sea (Gogou et al., 2007) and is coeval with pronounced cooling in the southern Adriatic Sea and the Aegean Sea (Geraga et al., 2010; Sangiorgi et al., 2003; Triantaphyllou et al., 2010). Kouli et al. (2012) suggest short-term episodes of climatic instability during this time interval associated with enhanced runoff conditions from 6600 to 6400 cal yr BP (Triantaphyllou et al., 2009a).

We also present evidence of a strong climatic change around $4200 \mathrm{cal} \mathrm{BP}$ (Figs. 7 and 8). Pollen-inferred climate reconstructions from Lakes Ledro, Accesa and Pergusa highlight a marked cooling event at ca. $4300-3800 \mathrm{cal} \mathrm{BP}$, corresponding to declines in winter and summer temperature decrease of $2{ }^{\circ} \mathrm{C}$ (Fig. 8). This event, also seen in the North Aegean Sea (Fig. 5d), is possibly the regional expression of the so-called " $4.2 \mathrm{kyr}$ event" observed in various regions of the world (e.g. Geraga et al., 2010). In the southeastern Aegean Sea, the $\mathrm{H}$ index records a humid phase between 5400 and $4300 \mathrm{kyr}$ that coincides with the deposition of a distinct sapropel-like layer and that is interrupted at $\sim 4.2$ cal kyr BP (Triantaphyllou et al., 2009b). Additionally, some Italian sites south of $43^{\circ} \mathrm{N}$ have shown temporary midHolocene deforestation at $4000 \mathrm{cal}$ yr BP that may have been caused by drought (Di Rita and Magri, 2009).

Magny et al. (2009) recognize a complex tripartite climatic oscillation between ca. 4300-3800 cal yr BP based on the Lake Accesa lake-level variations (Fig. 8). The three phases entail a phase characterized by dry conditions at ca. $4100-3950$ cal yr BP that is bracketed by marked by wet conditions, dated to ca. 4300-4100 and 3950-3850 cal yr BP, respectively. Pollen-based summer precipitation reconstructions for lakes Accesa, Ledro and Trifoglietti (Fig. 8) confirm the presence of such a dry event and provide some insight into the possible complexity of this climatic oscillation around the $4.2 \mathrm{kyr}$ event. The $4.2 \mathrm{kyr}$ event in the subtropical zone is a single short-lived event which may have corresponded to a climatic episode controlled from low latitudes (Marchant and Hooghiemstra, 2004) and can be associated with an expansion or northward displacement of the North African high-pressure zone. The dry episode centred at ca. 4150-3950 cal yr BP that is detected in Accesa, Ledro and Trifoglietti may be related to this short-lived dry phase, bracketed by two wet phases in the central Mediterranean.

\subsection{Precipitation seasonality, proxy sensitivity and climate reconstruction}

Enhanced rainfall near Lake Accesa between ca. 8900 and 7300 cal yr BP has been interpreted from speleothems recovered from Corchia Cave in the Apuan Alps (Zanchetta et al., 2007b) and from ca. 8200 to 7100 cal yr BP from Renella Cave, close to Corchia Cave (Zhornyak et al., 2011). The Renella record suggests that during the early to midHolocene, the region experienced very wet conditions associated to a substantial increase in flood activity (Zhornyak et al., 2011). However, during the first part of this period, the nearby lakes of Accesa and Fucino (e.g. Giraudi et al., 2011; Magny et al., 2007) experienced low-stand phases. Changes in precipitation seasonality may explain the apparent discrepancy between wetter conditions from speleothem records and drier conditions reported from lake-level reconstructions (Peyron et al., 2011; Magny et al., 2007, 2012b). This hypothesis is supported by the contrasting seasonal patterns of precipitation (strong Mediterranean conditions, with wet winters and dry summers) reconstructed for the early to 

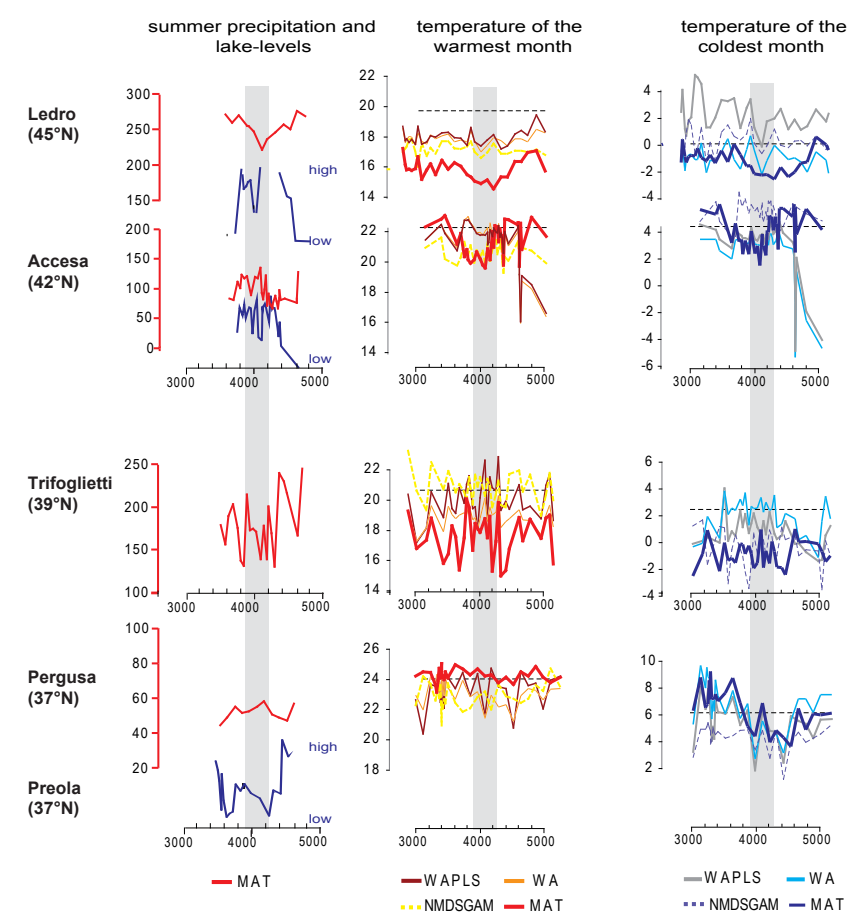

Fig. 8. Synthesis figure for the $4.2 \mathrm{kyr}$ event in Italy, and comparison with lake-level data.

mid-Holocene at Accesa from pollen data (Fig. 4; Peyron et al., 2011).

In the current study, we emphasize changes in precipitation seasonality by examining them at the regional scale. A direct comparison of pollen-inferred summer precipitation and lake-level changes at Lakes Ledro and Accesa from north-central Italy is shown in Fig. 6. Mediterranean conditions only appear to exist at Lake Ledro prior to $8500 \mathrm{cal} \mathrm{yr} \mathrm{BP}$ (Fig. 4). Mediterranean conditions terminate with increases for both summer and winter precipitation between 8300 and $7000 \mathrm{cal}$ yr BP. These results fit well with the relatively high lake levels at Ledro (Fig. 6), with the speleothem results from Corchia and Renella (Zanchetta et al., 2007b; Zhornyak et al., 2011), and with southern Alpine speleothems (Spötl et al., 2010). Southern and eastern Alpine speleothem records appear to register a humid period that is contemporaneous with the wettest phase identified at Corchia (i.e. ca. 8000 to 7300 cal yr BP) (Spötl et al., 2010). This humid period was interpreted as an increase in moisture sourced from the Mediterranean as opposed to the drier northwesterly air masses that affect the Alps (Spötl et al., 2010). At Accesa winter precipitation is particularly high around $8000 \mathrm{cal} \mathrm{yr} \mathrm{BP} \mathrm{(Fig.} \mathrm{4).} \mathrm{High} \mathrm{winter} \mathrm{precipita-}$ tion is consistent with the increase in flood activity due to increased storminess in the region suggested by Zhornyak et al. (2011), and is confirmed by a significant increase in winter precipitation between ca. 9500 and $7000 \mathrm{cal} \mathrm{yr} \mathrm{BP}$ in the northern Aegean Sea (Kotthoff et al., 2008, 2011).

Proxy records of precipitation from Sicily show higher rainfall between ca. 8500 and 7500 cal yr BP (Carburangeli Cave speleothems: Frisia et al., 2006; land snail shells, Favignana Island: Colonese et al., 2011). Colonese et al. (2011) take the thermal limits controlling periods of snail activity into account to suggest that the increased precipitation at this time may not have been an exclusive winter phenomenon but may have extended into spring and autumn. The two southern sites reported in this current study (Trifoglietti, Pergusa) both show higher winter precipitation, which is corroborated by Colonese et al. (2011) and Frisia et al. (2006), providing support that changes in seasonality may be major drivers for the high precipitation and lake levels at these sites from 10000 to 6500 cal yr BP (Figs. 4 and 6).

The current study confirms that lake levels appear to be good indicators of summer precipitation changes (Magny et al., 2007) and supports the assumption that lake levels, pollen, and isotopic data likely reflect processes linked to seasonality. Possible discrepancies between data could be reconciled considering the relative sensitivity of each site to changes in the seasonality of precipitation (Giraudi et al., 2011; Peyron et al., 2011) and the different residence times of water in their respective hydrological systems, but further evidence is needed to improve the general framework of climate evolution at this time, both at local and regional (Mediterranean Basin) scales.

\subsection{Climate processes and north-south partition}

To fully understand the timings and the relationships between regions and lakes within the Mediterranean Basin, we must understand the climatic mechanisms driving changes in moisture across the central Mediterranean during the Holocene. Tinner et al. (2009) have suggested that increasing humidity in coastal Sicily during the mid-Holocene reflects a decrease in the Hadley circulation (trade winds) and monsoonal activity after the boreal insolation maximum. This is in agreement with processes suggested for other areas of the Mediterranean (Tzedakis et al., 2009). An intense African monsoon strengthens the Hadley circulation (Gaetani et al., 2007), reinforcing the North Atlantic anticyclone and its blocking effect for possible intrusions of humid western airflow towards the Mediterranean. However, recent observations have also given evidence to possible influences of (1) sub-Saharan cyclones over the western-central Mediterranean (Knippertz and Wernli, 2010) and (2) rainstorms originating from the tropics over the eastern Mediterranean (Ziv et al., 2005). Moreover, Tzedakis (2007) and Tinner et al. (2009) have also pointed out the possible influence of local convective precipitation in response to the orbitally driven insolation maximum. The comparison of lake-level data and pollen-inferred estimates of climatic parameters along a north-south transect in the central Mediterranean 
clearly suggests that, over the Holocene period, the northern Mediterranean borderlands belong to a North Atlantic domain and show strong similarities with the European midlatitudes (Magny et al., 2011, 2012a), while the southern Mediterranean appears to be more strongly affected by subtropical influences.

Data in this study show progressive, millennial-scale changes in climate in response to changes in insolation. Data also show major centennial-scale climatic events, most evident at 8000 and $4500 \mathrm{cal} \mathrm{yr} \mathrm{BP}$. The $8000 \mathrm{cal} \mathrm{yr} \mathrm{BP}$ event may be related to the influence of the well-known $8.2 \mathrm{kyr}$ event associated with a final step of the deglaciation in the North Atlantic (Alley et al., 1997). The climatic oscillation around $4500-4000$ cal yr BP appears to have been a major climate change, not only in the eastern Mediterranean (Weis et al., 1993; Enzel et al., 2003; Arz et al., 2006; Drysdale et al., 2006) but also in the western Mediterranean.

Zhao et al. (2010) indicate that the climatic oscillation at 4000 cal yr BP may reflect a non-linear response of the climate system to (1) a gradual decrease of insolation and (2) key seasonal and inter-hemispherical changes in insolation. On the one hand, this orbital forcing resulted in a reorganization of the general atmospheric circulation, leading to a further southward migration of the ITCZ in the tropics (Haug et al., 2001; Denton et al., 2005). The southward migration of the ITCZ would have driven the westerlies southward, bringing more humidity to the mid-European latitudes and the north-central Mediterranean. On the other hand, in response to the decrease in insolation, cooling sea surface temperatures (Marchal et al., 2002) may have favoured the development of drier conditions over the south-central and eastern Mediterranean, south of ca. $40^{\circ} \mathrm{N}$, leading to the development of modern climate conditions.

\section{Conclusions}

There is strong agreement between summer precipitation and lake-level reconstructions at Lakes Accesa and Ledro in northern Italy and Lake Pergusa (Lake Preola for the lake levels) in Sicily throughout the Holocene. The strong relationship between the two confirms that lake level is most strongly a reflection of summer temperatures in the central Mediterranean.

The results presented here for precipitation and temperature reconstructions from the four lakes appear to confirm that northern and southern sites in the Mediterranean have opposing precipitation regimes during the Holocene (Magny et al., 2012b). The summer temperature curves appear to show the same pattern as for precipitation: warm/dry conditions in northern Italy and cool/wet conditions in Sicily are reconstructed during the early/mid-Holocene, and conditions reversed during the late Holocene. The Holocene climate history of the region was punctuated by centennial-scale events at ca. 8000,6500 and $4200 \mathrm{cal}$ yr BP. These short-term events and the north-south climate partition observed in Italy show strong similarities with those recognized in the Aegean Sea. The connections to short-lived climate events in the Aegean indicate that the climate events detected in the pollen-based climate reconstructions are in fact part of a broader regional climate forcing.

Acknowledgements. This study is a part of the LAMA ANR project (MSHE Ledoux, USR3124, CNRS) financially supported by the French CNRS (National Centre for Scientific Research). This project is supervised by Michel Magny (LCE, UMR6249, University of Franche-Comté) and Nathalie Combourieu-Nebout (LSCE, UMR1572 CEA-CNRS-UVSQ). This is LSCE contribution no. 4584. Simon Goring is currently supported by the NSF Macrosystems-funded PalEON Project. We also thank Stefania D'Angelo (WWF Nature Reserve Lago Preola e Gorghi Tondi). We also express special thanks to Elena Ortu and Boris Vannière for fruitful discussion.

Edited by: M.-F. Loutre

\section{References}

Allen, J. R. M., Watts, W. A., McGee, E., and Huntley, B.: Holocene environmental variability-the record from Lago Grande di Monicchio, Italy, Quaternary Int., 88, 69-80, 2002.

Alley, R. B., Mayewski, P. A., Sowers, T., Stuiver, M., Taylor, K. C., and Clark, P. U.: Holocene climatic instability: A prominent, widespread event 8200 yr ago, Geology, 25, 483-486, 1997.

Arz, H. W., Lamy, F., and Pätzold, J.: A pronounced dry event recorded around $4.2 \mathrm{ka}$ in brine sediments from the northern Red Sea, Quaternary Res., 66, 432-441, 2006.

Bar-Matthews, M. and Ayalon, A.: Mid-Holocene climate variations revealed by high-resolution speleothem records from Soreq Cave, Israel and their correlations with cultural changes, Holocene, 21, 163-172, 2011.

Bar-Matthews, M., Ayalon, A., and Kaufman, A.: Middle to Late Holocene (6500 yr period) paleoclimate in the eastern Mediterranean region from stable isotopic composition of speleothems from Soreq Cave, Israël, in: Environment and society in times of climate change, edited by: Issar, A. and Brown, N., Kluwer Academic, Dordrecht, 203-214, 1998.

Birks, H. H. and Birks, H. J. B.: Multi-proxy studies in palaeoclimnology, Veg. Hist. Archaeobot., 15, 235-251, 2006.

Birks, H. J. B., Heiri, O., Seppä, H., and Bjune, A. E.: Strengths and weaknesses of quantitative climate reconstructions based on late-Quaternary biological proxies, The Open Ecology Journal, 3, 68-110, 2010.

Brewer, S., Guiot, J., Sanchez-Goñi, M. F., and Klotz, S.: The climate in Europe during the Eemian: A multi-method approach using pollen data, Quaternary Sci. Rev., 27, 2303-2315, 2008.

Calò, C., Henne, P. D., Curry, B., Magny, M., Vescovi, E., La Mantia, T., Pasta, S., Vannière, B., and Tinner, W.: Spatio-temporal patterns of Holocene environmental change in southern Sicily, Palaeogeogr. Palaeocl., 323-325, 110-122, 2012. 
Colombaroli, D., Vannière, B., Chapron, E., Magny, M., and Tinner, W.: Fire-vegetation interactions during the Mesolithic-Neolithic transition at Lago dell'Accesa, Tuscany, Italy, Holocene, 18, 679-692, 2008.

Colonese, A. C., Zanchetta, G., Drysdale, R. N., Fallick, A. E., Manganelli, G., Lo Vetro, D., Martini, F., and Di Giuseppe, Z.: Stable isotope composition of Late Pleistocene-Holocene Eobania vermiculata (Müller, 1774) (Pulmonata, Stylommatophora) shells from the Central Mediterranean basin: Data from Grotta d'Oriente (Favignana, Sicily), Quaternary Int., 244, 76-87, 2011.

Davis, B. A. S. and Brewer, S.: Orbital forcing and role of the latitudinal insolation/ temperature gradient, Clim. Dynam., 32, 143$165,2009$.

Davis, B. A. S., Brewer, S., Stevenson, A. C., and Guiot, J.: The temperature of Europe during the Holocene reconstructed from pollen data, Quaternary Sci. Rev., 22, 1701-1716, 2003.

Denton, G., Alley, R., Comer, G., and Broecker, W.: The role of seasonality in abrupt climate change, Quaternary Sci. Rev., 24, 1159-1182, 2005.

Di Rita, F. and Magri, D.: Holocene drought, deforestation, and evergreen vegetation development in the central Mediterranean: a 5,500 year record from Lago Alimini Piccolo, Apulia, southeast Italy, Holocene, 19, 295-306, 2009.

Di Rita, F., Anzidei, A. P., and Magri, D.: A Lateglacial and early Holocene pollen record from Valle di Castiglione (Rome): Vegetation dynamics and climate implications, Quaternary Int., 288, 73-80, 2013.

Dormoy, I., Peyron, O., Combourieu Nebout, N., Goring, S., Kotthoff, U., Magny, M., and Pross, J.: Terrestrial climate variability and seasonality changes in the Mediterranean region between 15000 and 4000 years BP deduced from marine pollen records, Clim. Past, 5, 615-632, doi:10.5194/cp-5-615-2009, 2009.

Drescher-Schneider, R., de Beaulieu, J. L., Magny, M., WalterSimonnet, A. V., Bossuet, G., Millet, L., Brugiapaglia, E., and Drescher A.: Vegetation history, climate and human impact over the last 15000 years at Lago dell' Accesa (Tuscany, central Italy), Veg. Hist. Archaeobot., 16, 279-299, 2007.

Drysdale, R., Zanchetta, G., Hellstrom, J., Maas, R., Fallick, A., Pickett, M., Cartwright, I., and Piccini, L.: Late Holocene drought responsible for the collapse of Old World civilizations is recorded in an Italian cave flowstone, Geology, 34, 101-104, 2006.

Enzel, Y., Bookman, R., Sharon, D., Gvirtzmann, H., Dayan, U., Ziv, B., and Stein, M.: Late Holocene climates of the Near East deduced from Dead Sea level variations and regional winter rainfall, Quaternary Res., 60, 263-273, 2003.

Finné, M., Holmgren, K., Sundqvist, H. S., Weiberg, E., and Lindblom, M.: Climate in the eastern Mediterranean, and adjacent regions, during the past 6000 years, J. Archaeol. Sci., 38, 31533173, 2011.

Finsinger, W., Colombaroli, D., de Beaulieu, J. L., Valsecchi, V., Vannière, B., Vescovi, E., Chapron, E., Lotter, A. F., Magny, M., and Tinner, W.: Early to mid- Holocene climate change at Lago dell'Accesa (central Italy): climate signal or anthropogenic bias?, J. Quaternary Sci., 25, 1239-1247, 2010.

Frisia, S., Borsato, A., Mangini, A., Spötl, C., and Madonna, G.: Holocene climate variability from a discontinuous stalagmite record and the Mesolithic to Neolithic transition, Quaternary Res., 66, 388-400, 2006.
Gaetani, M., Baldi, M., Dalu, G. A., and Maracchi, G.: Connessioni tra il clima della regione Mediterranea e 1'Africa occidentale attraverso la circolazione meridiana di Hadley, in: Clima e cambiamenti climatici, edited by: Carli, B., Cavarretta, G., Colacino, M., and Fuzzi, S., Roma, Consiglio Nazionale delle Ricerche, 23-26, 2007.

Geraga, M., Ioakim, C., Lykousis, V., Tsaila-Monopolis, S., and Mylona, G.: The high-resolution palaeoclimatic and palaeoceanographic history of the last 24,000 years in the central Aegean Sea, Greece, Palaeogeogr. Palaeocl., 287, 101-115, 2010.

Giorgi, F. and Lionello, P.: Climate change projections for the Mediterranean region, Global Planet. Change, 63, 90-104, 2008.

Giraudi, C., Magny, M., Zanchetta, G., and Drysdale, R. N.: The Holocene climate evolution of the Mediterranean Italy: a review of the geological continental data, Holocene, 21, 105-115, doi:10.1177/0959683610377529, 2011.

Gogou, A., Bouloubassi, I., Lykousis, V., Arnaboldi, M., Gaitani, P., and Meyers, P. A.: Organic geochemical evidence of abrupt late glacial-Holocene climate changes in the North Aegean Sea, Palaeogeogr. Palaeocl., 256, 1-20, 2007.

Goring, S., Pellatt, M. G., Lacourse, T., Walker, I. R., and Mathewes R. W.: A new methodology for reconstructing climate and vegetation from modern pollen assemblages: An example from British Columbia, J. Biogeogr., 36, 626-638, 2009.

Guiot J.: Methodology of the last climatic cycle reconstruction in France from pollen data, Palaeogeogr. Palaeocl., 80, 49-69, 1990.

Haug, G. H., Hughen, K. A., Sigman, D. M., Peterson, L. C., and Röhl, U.: Southward migration of the Intertropical Convergence Zone through the Holocene, Science, 293, 1304-1308, 2001.

Joannin, S., Brugiapaglia, E., de Beaulieu, J.-L., Bernardo, L., Magny, M., Peyron, O., Goring, S., and Vannière, B.: Pollenbased reconstruction of Holocene vegetation and climate in southern Italy: the case of Lago Trifoglietti, Clim. Past, 8, 19731996, doi:10.5194/cp-8-1973-2012, 2012.

Joannin, S., Vannière, B., Galop, D., Peyron, O., Haas, J. N., Gilli, A., Chapron, E., Wirth, S. B., Anselmetti, F., Desmet, M., and Magny, M.: Climate and vegetation changes during the Lateglacial and early-middle Holocene at Lake Ledro (southern Alps, Italy), Clim. Past, 9, 913-933, doi:10.5194/cp-9-913-2013, 2013.

Klotz, S., Guiot, J., and Mosbrugger, V.: Continental European Eemian and early Wurmian climate evolution: comparing signals using different quantitative reconstruction approaches based on pollen, Global Planet. Change, 36, 277-294, 2003.

Knippertz, P. and Wernli, H.: A Lagrangian climatology of Tropical moisture exports to the Northern Hemispheric extratropics, J. Climate, 23, 987-1003, 2010.

Kotthoff, U., Pross, J., Müller, U. C., Peyron, O., Schmiedl, G., and Schulz, H.: Climate Dynamics in the borderlands of the Aegean Sea during formation of Sapropel S1 deduced from a marine pollen record, Quaternary Sci. Rev., 27, 832-845, 2008.

Kotthoff, U., Koutsodendris, A., Pross, J., Schmiedl, G., Bornemann, A., Kaul, C., Marino, G., Peyron, O., and Schiebel, R.: Impact of late glacial cold events on the Northern Aegean region reconstructed from marine and terrestrial proxy data, J. Quaternary Sci., 26, 86-96, 2011. 
Kouli, K., Gogou, A., Bouloubassi, I., Triantaphyllou, M. V., Ioakim, C., Katsouras, G., Roussakis, G., and Lykousis, V.: Late postglacial paleoenvironmental change in the northeastern Mediterranean region: Combined palynological and molecular biomarker evidence, Quaternary Int., 261, 118-127, 2012.

Kühl, N., Moschen, R., Wagner, S., Brewer, S., and Peyron, O.: A multiproxy record of Late Holocene natural and anthropogenic environmental change from the Sphagnum peat bog Dürres Maar, Germany: implications for quantitative climate reconstructions based on pollen, J. Quaternary Sci., 25, 675-688, 2010.

Lionello, P. (Ed.): The climate of the Mediterranean region, From the past to the future, Elsevier, ISBN: 9780124160422, 2012.

Lionello, P., Malanotte-Rizzoli, P., Boscolo, R., Alpert, P., Artale, V., Li, L., Luterbacher, J., May, W., Trigo, R., Tsimplis, M., Ulbrich, U., and Xoplaki, E.: The Mediterranean climate: An overview of the main characteristics and issues, in: Mediterranean Climate Variability, edited by: Lionello, P., MalanotteRizzoli, P., and Boscolo, R., Developments in Earth \& Environmental Sciences 4, Elsevier, 1-26, 2006.

Magny, M., Bégeot, C., Guiot, J., and Peyron, O.: Contrasting patterns of hydrological changes in Europe in response to Holocene climate cooling phases, Quaternary Sci. Rev. 22, 1589-1596, 2003.

Magny, M., de Beaulieu, J. L., Drescher-Schneider, R., Vannière, B., Walter-Simonnet, A. V., Miras, Y., Millet, L., Bossuet, G., Peyron, O., Brugiapaglia, E., and Leroux, A.: Holocene climate changes in the central Mediterranean as recorded by lake-level fluctuations at Lake Accesa (Tuscany, Italy), Quaternary Sci. Rev., 26, 1736-1758, 2007.

Magny, M., Vannière, B., Zanchetta, G., Fouache, E., Touchais, G., Petrika, L., Coussot, C., Walter-Simonnet, A. V., and Arnaud, F.: Possible complexity of the climatic event around 4300$3800 \mathrm{cal} \mathrm{BP}$ in the central and western Mediterranean, Holocene, 19, 823-833, 2009.

Magny, M., Vannière, B., Calo, C., Millet, L., Leroux, A., Peyron, O., Zanchetta, G., La Mantia, T., and Tinner, W.: Holocene hydrological changes in south-western Mediterranean as recorded by lake-level fluctuations at Lago Preola, a coastal lake in southern Sicily, Italy, Quaternary Sci. Rev., 30, 2459-2475, 2011.

Magny, M., Joannin, S., Galop, D., Vannière, B., Haas, J. N., Bassetti, M., Bellintani, P., Scandolari, R., and Desmet, M.: Holocene palaeohydrological changes in the northern Mediterranean borderlands as reflected by the lake-level record of Lake Ledro, northeastern Italy, Quaternary Res., 77, 382-396, 2012a.

Magny, M., Peyron, O., Sadori, L., Ortu, E., Zanchetta, G., Vannière, B., and Tinner, W.: Contrasting patterns of precipitation seasonality during the Holocene in the south- and northcentral Mediterranean, J. Quaternary Sci., 27, 290-296, 2012 b.

Magri, D. and Sadori, L.: Late Pleistocene and Holocene pollen stratigraphy at Lago di Vico (central Italy), Veg. Hist. Archaeobot., 8, 247-260, 1999.

Marchal, O., Cacho, I., Stocker, T., Grimalt, J., Calvo, E., Martrat, B., Shackleton, N., Vautravers, M., Cortijo, E., van Kreveld, S., Andersson, C., Koç, N., Chapman, M., Sbaffi, L., Duplessy, J. C., Sarnthein, M., and Turon, J. L.: Apparent long-term cooling of the sea surface in the northeast Atlantic and Mediterranean during the Holocene, Quaternary Sci. Rev., 21, 455-483, 2002.
Marchant, R. and Hooghiemstra, H.: Rapid environmental change in African and South American tropics around 4000 years before present: a review, Earth-Sci. Rev., 66, 217-260, 2004.

Mercuri, A. M., Mazzanti, M., Torri, P., Vigliotti, L., Bosi, G., Florenzano, A., Olmi, L., and N'siala, I.: A marine/terrestrial integration for mid-late Holocene vegetation history and the development of the cultural landscape in the Po valley as a result of human impact and climate change, Veg. Hist. Archaeobot., 21, 353-372, doi:10.1007/s00334-012-0352-4, 2012.

New, M., Lister, D., Hulme, M., and Makin, I.: A high resolution dataset of surface climate over global land areas, Clim. Res., 21, $1-25,2002$.

Overpeck, J. T., Webb III, T., and Prentice, I. C.: Quantitative interpretation of fossil pollen spectra: dissimilarity coefficients and the method of modern analogs, Quaternary Res., 23, 87-108, 1985.

Ozenda, P.: Vegetation Map of the Council of Europe Member States, Council of Europe, Strasbourg, 100 pp., 1979.

Pérez-Obiol, R. and Sadori, L.: Similarities and dissimilarities, synchronisms and diachronisms in the Holocene vegetation history of the Balearic Islands and Sicily, Veg. Hist. Archaeobot., 16, 259-265, 2007.

Peyron, O., Bégeot, C., Brewer, S., Heiri, O., Magny, M., Millet, L., Ruffaldi, P., Van Campo, E., and Yu, G.: Lateglacial climate in the Jura Mountains based on pollen, lake-levels, and chironomids, Quaternary Res., 64, 197-211, 2005.

Peyron, O., Jolly, D., Braconnot, P., Bonnefille, R., Guiot, J., Wirrmann, D., Chalié, F., and pollen contributors: Quantitative reconstructions of hydrological conditions in Africa 6000 years ago: model-data comparison, J. Geophys. Res.-Atmos., 111, D24110, doi:10.1029/2006JD007396, 2006.

Peyron, O., Goring, S., Dormoy, I., Kotthoff, U., Pross, J., de Bealieu, J. L., Drescher-Schneider, R., and Magny, M.: Holocene seasonality changes in the central Mediterranean region reconstructed from the pollen sequences of Lake Accesa (Italy) and Tenaghi Philippon (Greece), Holocene, 21, 131-146, 2011.

Piccarreta, M., Caldara, M., Capolongo, D., and Boenzi F.: Holocene geomorphic activity related to climatic change and human impact in Basilicata, Southern Italy, Geomorphology, 128, 137-147, 2011.

Pross, J., Kotthoff, U., Müller, U. C., Peyron, O., Dormoy, I., Schmiedl, G., Kalaitzidis, S., and Smith, A. M.: Massive perturbation in terrestrial ecosystems of the Eastern Mediterranean region associated with the $8.2 \mathrm{kyr}$ climatic event, Geology, 37, 887-890, 2009.

Renssen, H., Goosse, H., and Fichefet, T.: Modeling the effect of freshwater pulses on the early Holocene climate: The influence of high-frequency climate variability, Paleoceanography, 17, 10291035, 2002.

Roberts, N., Brayshaw, D., Kuzucuoğlu, C., Perez, R., and Sadori, L.: The mid-Holocene climatic transition in the Mediterranean: Causes and consequences, Holocene, 21, 3-13, 2011.

Rohling, E. J., Cane, T. R., Cooke, S., Sprovieri, M., Bouloubassi, I., Emeis, K. C., Schiebel, R., Kroon, D., Jorissen, F. J., Lorre, A., and Kemp, A. E. S.: African monsoon variability during the previous interglacial maximum, Earth Planet. Sc. Lett., 202, 61$75,2002$. 
Sadori, L. and Giardini, M.: Charcoal analysis, a method to study vegetation and climate of the Holocene: The case of Lago di Pergusa, Sicily (Italy), Geobios-Lyon, 40, 173-180, 2007.

Sadori, L. and Narcisi, B.: The postglacial record of environmental history from Lago di Pergusa, Sicily, Holocene, 11, 655-671, 2001.

Sadori, L., Giraudi, C., Petitti, P., and Ramrath, A.: Human impact at Lago di Mezzano (central Italy) during the Bronze Age: a multidisciplinary approach, Quaternary Int., 113, 5-17, 2004.

Sadori, L., Zanchetta, G., and Giardini, M.: Last Glacial to Holocene palaeoenvironmental evolution at Lago di Pergusa (Sicily, Southern Italy) as inferred by pollen, microcharcoal, and stable isotopes, Quaternary Int., 181, 4-14, 2008.

Sadori, L., Jahns, S., and Peyron, O.: Mid-Holocene vegetation history of the central Mediterranean, Holocene, 21, 117-129, 2011.

Sadori, L., Ortu, E., Peyron, O., Zanchetta, G., Vannière, B., Desmet, M., and Magny, M.: The last 7 millennia of vegetation and climate changes at Lago di Pergusa (central Sicily, Italy), Clim. Past Discuss., 9, 2059-2094, doi:10.5194/cpd-92059-2013, 2013.

Sangiorgi, F., Capotondi, L., Nebout, N. C., Vigkiotti, L., Brinkhuis, H., Giounta, S., Lotter, A. F., Morigi, C., Negri, A., and Reichart, G.-J.: Holocene seasonal sea surface temperature variation in the southern Adriatic Sea inferred from a multiproxy approach, J. Quaternary Sci., 18, 723-732, 2003.

Simonneau, A., Chapron, E., Vannière, B., Wirth, S. B., Gilli, A., Di Giovanni, C., Anselmetti, F. S., Desmet, M., and Magny, M.: Mass-movement and flood-induced deposits in Lake Ledro, southern Alps, Italy: implications for Holocene palaeohydrology and natural hazards, Clim. Past, 9, 825-840, doi:10.5194/cp-9825-2013, 2013.

Spötl, C., Nicolussi, K., Patzelt, G., and Boch, R.: Humid climate during deposition of sapropel 1 in the Mediterranean Sea: assessing the influence on the Alps, Global Planet. Change, 71, 242248, 2010.

Ter Braak, C. J. F. and Juggins, S.: Weighted averaging partial least squares regression (WA-PLS): An improved method for reconstructing environmental variables from species assemblages, Hydrobiologia, 269/270, 485-502, 1993.

Ter Braak, C. J. F. and van Dam, H.: Inferring pH from diatoms: A comparison of old and new calibration methods, Hydrobiologia, 178, 209-223, 1989.

Tinner, W., van Leeuwen, J. F. N., Colombaroli, D., Vescovi, E., van der Knaap, W. O., Henne, P. H., Pasta, S., D’ Angelo, S., and La Mantia, T.: Holocene environmental and climatic changes at Gorgo Basso, a coastal lake in southern Sicily, Italy, Quaternary Sci. Rev., 28, 1498-1510, 2009.

Triantaphyllou, V., Antonarakou, A., Kouli, K., Dimiza, M., Kontakiotis, G., Papanikolaou, M. D., Lianou, V., Ziveri, P., Mortyn, G., Lykousis, V., and Dermitzakis, M. D.: Late Glacial-Holocene ecostratigraphy of the south-eastern Aegean Sea, based on plankton and pollen assemblages, Geo-Mar. Lett., 29, 249-267, 2009a.

Triantaphyllou, M. V., Ziveri, P., Gogou, A., Marino, G., Lykousis, V., Bouloubassi, I., Emeis, K.-C., Kouli, K., Dimiza, M., RosellMele, A., Papanikolaou, M., Katsouras, G., and Nunez, N.: Late Glacial-Holocene climate variability at the south-eastern margin of the Aegean Sea, Mar. Geol., 266, 182-197, 2009b.
Triantaphyllou, M. V., Antonarakou, A., Dimiza, M., and Anagnostou, Ch.: Calcareous nannofossil and planktonic foraminiferal distributional patterns during deposition of sapropels S6, S5 and $\mathrm{S} 1$ in the Libyan Sea (Eastern Mediterranean), Geo-Mar. Lett., 30, 1-13, 2010.

Trigo, R. M., Xoplaki, E., Zorita, E., Luterbacher, J., Krichak, S. O., Alpert, P., Jacobeit, J., Sáenz, J., Fernández, J., GonzálezRouco, F., Garcia-Herrera, R., Rodo, X., Brunetti, M., Nanni, T., Maugeri, M., Türke, M., Gimeno, L., Ribera, P., Brunet, M., and Trigo, I. F.: Relations between variability in the Mediterranean region and Mid-latitude variability, in: The Mediterranean Climate: an overview of the main characteristics and issues, edited by: Lionello, P., Malanotte-Rizzoli, P., and Boscolo, R., Elsevier, Amsterdam, 179-226, 2006.

Tzedakis, P. C.: Seven ambiguities in the Mediterranean palaeoenvironmental narrative, Quaternary Sci. Rev., 26, 2042-2066, 2007.

Tzedakis, P. C., Palike, H., Roucoux, K. H., and de Abreu, L.: Atmospheric methane, southern European vegetation and low-mid latitude links on orbital and millennial timescales, Earth Planet. Sc. Lett., 277, 307-317, 2009.

Vaks, A., Bar-Matthews, M., Ayalon, A., Matthews, A., Frumkin, A., Dayan, U., Halicz, L., Almogi-Labin, A., and Schilman, B.: Paleoclimate and location of the border between Mediterranean climate region and the Saharo-Arabian Desert as revealed by speleothems from the northern Negev Desert, Israel, Earth Planet. Sc. Lett., 249, 384-399, 2006.

Vannière, B., Colombaroli, D., Chapron, E., Leroux, A., Tinner, W., and Magny, M.: Climate versus human-driven fire regimes in Mediterranean landscapes: The Holocene record of Lago dell'Accesa (Tuscany, Italy), Quaternary Sci. Rev., 27, 11811196, 2008.

Vannière, B., Power, M. J., Roberts, N., Tinner, W., Carrion, J., Magny, M., Bartlein, P., and Contributors Data: CircumMediterranean fire activity and climate changes during the mid Holocene environmental transition (8500-2500 cal yr BP), Holocene, 21, 53-73, 2011.

Vannière, B., Magny, M., Joannin, S., Simonneau, A., Wirth, S. B., Hamann, Y., Chapron, E., Gilli, A., Desmet, M., and Anselmetti, F. S.: Orbital changes, variation in solar activity and increased anthropogenic activities: controls on the Holocene flood frequency in the Lake Ledro area, Northern Italy, Clim. Past, 9, 1193-1209, doi:10.5194/cp-9-1193-2013, 2013.

Weis, H., Courty, M. A., Wetterstrom, W., Guichard, F., Senior, L., Meadow, R., and Curnow, A.: The genesis and collapse of third millennium North Mesopotamian civilization, Science, 261, 995-1004, 1993.

Williams, J. W., Shuman, B., Bartlein, P. J., Whitmore, P. J., Gajewski, K., Sawada, M., Minckley, T., Shafer, S., Viau, A. E., Webb III, T., Anderson, P. M., Brubaker, L. B., Whitlock, C., and Davis, O. K.: An Atlas of Pollen-Vegetation-Climate Relationships for the United States and Canada, American Association of Stratigraphic Palynologists Foundation, Dallas, TX, 293 pp., 2006.

Zanchetta, G., Borghini, A., Fallick, A. E., Bonadonna, F. P., and Leone, G.: Late Quaternary palaeohydrology of Lake Pergusa (Sicily, southern Italy) as inferred by stable isotopes of lacustrine carbonates, J. Paleolimnol., 38, 227-239, 2007a. 
Zanchetta, G., Drysdale, R. N., Hellstrom, J. C., Fallick, A. E., Isola, I., Gagan, M., and Pareschi, M. T.: Enhanced rainfall in the western Mediterranean during deposition of sapropel S1: stalagmite evidence from Corchia cave (Central Italy), Quaternary Sci. Rev., 26, 279-286, 2007b.

Zhao, C., Yu, Z., and Zhao, Y.: Holocene climate trend, variability, and shift documented by lacustrine stable-isotope record in the northeastern United States, Quaternary Sci. Rev., 29, 1831-1843, 2010 .
Zhornyak, L. V., Zanchetta, G., Drysdale, R. N., Hellstrom, J. C., Isola, I., Regattieri, E., Piccini, L., Baneschi, I., and Couchoud, I.: Stratigraphic evidence for a "pluvial phase" between ca. 8200-7100 ka from Renella cave (Central Italy), Quaternary Sci. Rev., 30, 409-417, 2011.

Ziv, B., Saaroni, H., Baharad, A., Yekutieli, D., and Alpert, P.: Indications of aggravation in summer heat conditions over the Mediterranean Basin, Geophys. Res. Lett., 32, L12706, doi:10.1029/2005GL022796, 2005. 